\title{
Article
}

\section{TRPM2 Oxidation Activates Two Distinct Potassium Channels in Melanoma Cells through Intracellular Calcium Increase}

\author{
Loretta Ferrera $^{1,2}{ }^{1}$, Raffaella Barbieri ${ }^{1}{ }^{(D}$, Cristiana Picco ${ }^{1}\left(\mathbb{D}\right.$, Paolo Zuccolini ${ }^{1}$, Alessia Remigante ${ }^{1,3} \mathbb{D}^{\text {, }}$ \\ Sara Bertelli ${ }^{1}$, Maria Rita Fumagalli ${ }^{1,4}$, Giovanni Zifarelli ${ }^{1}$, Caterina A. M. La Porta ${ }^{1,4}$ (D), Paola Gavazzo ${ }^{1}$ \\ and Michael Pusch 1,*(D)
}

\section{check for}

updates

Citation: Ferrera, L.; Barbieri, R.; Picco, C.; Zuccolini, P.; Remigante, A.; Bertelli, S.; Fumagalli, M.R.; Zifarelli, G.; La Porta, C.A.M.; Gavazzo, P.; et al. TRPM2 Oxidation Activates Two Distinct Potassium Channels in Melanoma Cells through Intracellular Calcium Increase. Int. J. Mol. Sci. 2021, 22, 8359. https://doi.org/ $10.3390 /$ ijms 22168359

Academic Editor: Alfonso Baldi

Received: 28 June 2021

Accepted: 2 August 2021

Published: 4 August 2021

Publisher's Note: MDPI stays neutral with regard to jurisdictional claims in published maps and institutional affiliations.

Copyright: (c) 2021 by the authors. Licensee MDPI, Basel, Switzerland. This article is an open access article distributed under the terms and conditions of the Creative Commons Attribution (CC BY) license (https:// creativecommons.org/licenses/by/ $4.0 /)$.
1 Biophysics Institute, National Research Council, 16149 Genova, Italy; Loretta.Ferrera@unige.it (L.F.); raffaella.barbieri@ibf.cnr.it (R.B.); cristiana.picco@ibf.cnr.it (C.P.); paolo.zuccolini@ibf.cnr.it (P.Z.); alessia.remigante@ibf.cnr.it (A.R.); sara.bertelli@ibf.cnr.it (S.B.); mariarita.fumagalli@gmail.com (M.R.F.); giovanni.zifarelli@ibf.cnr.it (G.Z.); caterina.laporta@unimi.it (C.A.M.L.P.); paola.gavazzo@ibf.cnr.it (P.G.)

2 U.O.C. Genetica Medica, Istituto di Ricovero e Cura a Carattere Scientifico (IRCCS) Istituto Giannina Gaslini, 16147 Genoa, Italy

3 Department of Chemical, Biological, Pharmaceutical and Environmental Sciences, University of Messina, 98166 Messina, Italy

4 Center for Complexity and Biosystems, Department of Environmental Science and Policy, University of Milan, 20133 Milano, Italy

* Correspondence: michael.pusch@ibf.cnr.it

\begin{abstract}
Tumor microenvironments are often characterized by an increase in oxidative stress levels. We studied the response to oxidative stimulation in human primary (IGR39) or metastatic (IGR37) cell lines obtained from the same patient, performing patch-clamp recordings, intracellular calcium $\left(\left[\mathrm{Ca}^{2+}\right]_{\mathrm{i}}\right)$ imaging, and RT-qPCR gene expression analysis. In IGR39 cells, chloramine-T (Chl-T) activated large $\mathrm{K}^{+}$currents (KROS) that were partially sensitive to tetraethylammonium (TEA). A large fraction of KROS was inhibited by paxilline-a specific inhibitor of large-conductance $\mathrm{Ca}^{2+}$ activated BK channels. The TEA-insensitive component was inhibited by senicapoc-a specific inhibitor of the $\mathrm{Ca}^{2+}$-activated KCa3.1 channel. Both BK and KCa3.1 activation were mediated by an increase in $\left[\mathrm{Ca}^{2+}\right]_{\mathrm{i}}$ induced by Chl-T. Both KROS and $\left[\mathrm{Ca}^{2+}\right]_{\mathrm{i}}$ increase were inhibited by ACA and clotrimazole-two different inhibitors of the calcium-permeable TRPM2 channel. Surprisingly, IGR37 cells did not exhibit current increase upon the application of Chl-T. Expression analysis confirmed that the genes encoding BK, KCa3.1, and TRPM2 are much more expressed in IGR39 than in IGR37. The potassium currents and $\left[\mathrm{Ca}^{2+}\right]_{\mathrm{i}}$ increase observed in response to the oxidizing agent strongly suggest that these three molecular entities play a major role in the progression of melanoma. Pharmacological targeting of either of these ion channels could be a new strategy to reduce the metastatic potential of melanoma cells, and could complement classical radio- or chemotherapeutic treatments.
\end{abstract}

Keywords: melanoma; oxidative stress; potassium channels; intracellular calcium; TRP channels

\section{Introduction}

Ion channels are specialized membrane proteins involved in several physiological functions, such as electrical signaling, signal transduction, and transport of ions small molecules across biological membranes in response to specific stimuli $[1,2]$. Nevertheless, ion channels can also be implicated in the development of a large variety of diseases where oxidative stress (OS) plays a major role [3], including neurodegenerative diseases [4], cardiovascular diseases [5], diabetes [6], aging [7], and cancer [8]. In this regard, the factors that favor the insurgence of cancer and its progression to a metastatic state depend on the production of free radicals, such as reactive oxygen species (ROS) $[9,10]$. In fact, the onset of many tumors occurs via the deleterious effects of free radicals associated with accumulation of damage over a period of years. Although the continuous accumulation of cellular and 
molecular changes is the major driving force for the initiation and progression of cancer, the underlying mechanisms can be promising targets for therapeutic mediation [8].

Oxidative stress is frequently described as the balance between the production of ROS in biological systems, and the ability of the latter to defend themselves through their endogenous antioxidant machinery [11-13]. Thus, when oxidants are produced in excess, or when the antioxidant defenses are ineffective, this balance can be perturbed, thus resulting in increased oxidative stress. In these conditions, biomolecules-such as nucleic acids, membrane lipids, enzymes, and proteins—can be damaged beyond their repair capacity. In this regard, ion channels possess sulfur-containing cysteine and methionine residues that can be targeted by ROS, thus altering channel function, including gating and conductivity properties, as well as associated signaling pathways [14]. Specifically, the amino acid methionine is particularly susceptible to oxidation due to the presence of a highly reactive sulfur atom within a hydrophobic side chain. In fact, in oxidative conditions induced by either endogenous species or exogenous reagents, methionine is oxidized to methionine sulfoxide (met-O), thus altering the secondary structure of the target protein [15]. Among oxidant agents, chloramine- $\mathrm{T}$ (Chl-T) efficiently oxidizes methionine, and represents an ideal tool to mimic abnormal intracellular ROS levels [16,17]. The chemical and physical changes caused by methionine oxidation drastically alter the functions of ion channels, and consequently, the effect of oxidative stress on ion channels could become an essential part of a potential pathogenic mechanism in cancer cells $[16,18]$. In fact, both the abnormal production of ROS and alterations in ion channel activity can promote many processes causing development and progression in a tumor cell, such as cellular proliferation, evasion of apoptosis or anoikis, metastasis, and angiogenesis [19,20].

Several types of $\mathrm{K}^{+}$channels are overexpressed in cancer, and are believed to be important tumorigenic agents [21]. Nevertheless, due to the high number of ion channels and the high complexity of the field, progress in understanding is often slow and focused on single molecules. Specifically in melanoma, the role of ion channels has still not been elucidated in detail [22].

Malignant melanoma-a neoplasm arising from the malignant transformation of melanocytes-is predominantly a disease of the skin, but in rare instances can occur at other sites, including the mucous membranes and the eye [23]. It is one of the most aggressive and deadly skin cancers, and is surpassed only by lung cancer [24]. The vulnerability of melanocytes to oxidative stress can be explained by their great ability to produce melanin. In fact, the melanosome is thought to be the main source of the high levels of ROS observed in melanocytes and melanoma cells [20]. Therefore, a better molecular characterization is urgently needed in order to identify the key drivers and pathways involved. In addition, the identification of prognostic molecular markers of the metastatic process is critical for designing therapeutic modalities for reducing the occurrence of metastasis.

Among the ion channels expressed in melanoma, the large-conductance $\mathrm{K}^{+}$channelalso known as the BK channel, and encoded by the KCNMA1 gene-plays a complex and ambiguous role in human cancer [25-29]. BK channels are activated by voltage and intracellular calcium in a cooperative manner [30]. Expression of BK channels is increased in cancerous compared to healthy cells, and correlates with the malignancy of the tumors. It often contributes to the modulation of hormone-dependent cancers-such as breast, prostate, and cervical cancer-but it has also been proposed as a remedy target in other types of cancer, such as melanoma. Notably, it has been found that ROS modulate BK channel activity, although the effect appears to be variable, depending on the cell model used. For example, in fibroblasts, the oxidative stress inducer $\mathrm{H}_{2} \mathrm{O}_{2}$ favors BK channel activity via a mechanism involving PKC [31]. In HEK293 cells overexpressing BK channels, the effect of $\mathrm{H}_{2} \mathrm{O}_{2}$ was instead activatory or inhibitory, depending on the site of applicationnamely, a direct intracellular application, possibly involving cysteine oxidation, led to BK channel inhibition, whereas extracellular $\mathrm{H}_{2} \mathrm{O}_{2}$ application that activates the PI3Kdependent transduction pathway led to BK channel activation [32]. In addition, the extracellular application of oxidizing agents-such as 5'5-dithiobis(2-nitrobenzoic acid) 
(DTNB) or dithiothreitol (DTT)—significantly increases BK channel activity in the isolated smooth muscle cells of rabbit pulmonary arteries, resulting in a reduction in intracellular glutathione (GSH) levels, thus indicating that alterations by the GSH are connected with BK activity [33].

KCa3.1, encoded by the KCNN4 gene, is another member of the $\mathrm{Ca}^{2+}$-activated $\mathrm{K}^{+}$ channel family, with a smaller single-channel conductance than $\mathrm{BK}$, and lacking any significant voltage dependence. Its aberrant expression has been reported in several cancer types, such as colorectal and pancreatic cancers, where KCa3.1 channels are expressed on the inner mitochondrial membrane, and have been proposed to modulate important mitochondrial functions, such as oxidative phosphorylation [22,34-37].

Another class of ion channel implicated in cancer is transient receptor potential (TRP) channels. Since most TRP channels are permeable to $\mathrm{Ca}^{2+}$, increased TRP channel expression is expected to enhance intracellular $\mathrm{Ca}^{2+}$ levels and impact $\mathrm{Ca}^{2+}$ signaling. Indeed, overexpression of several TRP channel genes in various cancer types is compatible with a switch of cancer cells to an aberrant proliferative state [38]. Related to the aberrant proliferation and the often hypoxic environment, most cancers are characterized by enhanced oxidative stress $[39,40]$, which can be directly sensed by various TRP channels, including TRPV1 [41], TRPV2 [17], and TRPM2 [42]. Interestingly, TRPM2 is implicated in several physiological and pathological pathways involving oxidative stress, and its activation has been generally associated with a large increase in intracellular $\mathrm{Ca}^{2+}[43-48]$.

Based on these considerations, the exploitation of ion channels as new molecular targets in cancer therapy [34,49-52] is a general goal. In the present investigation, the patchclamp technique, quantitative measurements of intracellular $\mathrm{Ca}^{2+}$ levels, and RT-qPCR have been used to investigate the response to the oxidizing reagent Chl-T in IGR39 cells-a cell line derived from a human primary melanoma-and in IGR37 cells, which instead are derived from a metastasis of the same patient.

\section{Results}

\subsection{Activation of Large Currents by Chl-T in IGR39 but Not in IGR37 Cells}

Tumor microenvironments are characterized by an increase in oxidative stress [39,40]. In order to investigate the electrophysiological responses of primary melanoma IGR39 cells to oxidative reagents in the whole-cell patch-clamp configuration, we applied the mild oxidant Chl-T. Invariably, perfusion of $0.5 \mathrm{mM}$ Chl-T elicited very large outward currents, with a 3.3 -fold increase at $+100 \mathrm{mV}$ compared to cells under standard conditions (normalized current increase at $100 \mathrm{mV}: 3.29 \pm 0.62, p=0.0009, n=16$ ) (Figure 1a). After washout of Chl-T, currents slowly recovered, almost to the level preceding the application of the oxidant (data not shown). Surprisingly, application of Chl-T to IGR37 cells-metastatic cells derived from the same patient- did not elicit any current increase (normalized change of current at $100 \mathrm{mV}: 0.86 \pm 0.12, p=0.266, n=7$ ) (Figure $1 \mathrm{~b}$ ).

\subsection{Identification of the Large-Conductance (BK) $\mathrm{K}^{+}$Channel as a Major Current Component Activated by Chl-T}

In order to investigate whether $\mathrm{K}^{+}$channels are involved in the Chl-T-activated currents in IGR39 cells, we applied tetraethylammonium (TEA) — an inhibitor of several $\mathrm{K}^{+}$channel classes (STD TEA, see Table 1). Figure 2 shows that the addition of $30 \mathrm{mM}$ TEA almost completely inhibited Chl-T-evoked outward currents, confirming that they are mediated to a large extent by $\mathrm{K}^{+}$currents, which we call KROS.

Table 1. Composition of the extracellular solutions (in $\mathrm{mM}$; $\mathrm{pH}$ was 7.3).

\begin{tabular}{ccccccccc}
\hline & $\mathbf{N a C l}$ & $\mathbf{K C l}$ & $\mathbf{C a C l}_{\mathbf{2}}$ & $\mathbf{M g C l}_{\mathbf{2}}$ & HEPES & TEACl & Mannitol & EGTA \\
\hline STD & 145 & 5 & 2 & 1 & 10 & - & - & - \\
STD 0 Ca $^{2+}$ & 145 & 5 & - & 1 & 10 & - & - & 3 \\
STD TEA & 115 & 5 & 2 & 1 & 10 & 30 & - & - \\
ISO-TEA & 60 & 5 & 2 & 1 & 10 & 30 & 100 & - \\
\hline
\end{tabular}


a

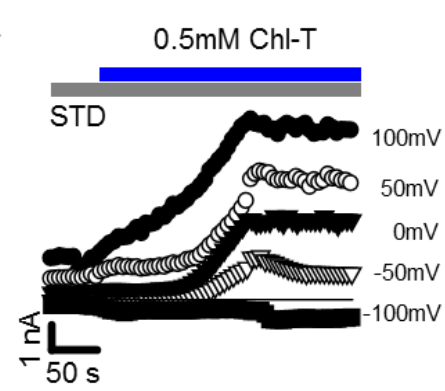

b

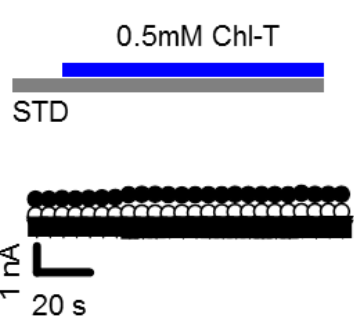

STD

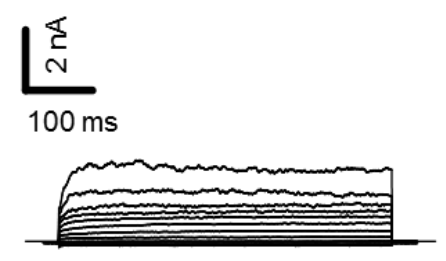

STD
Chl-T

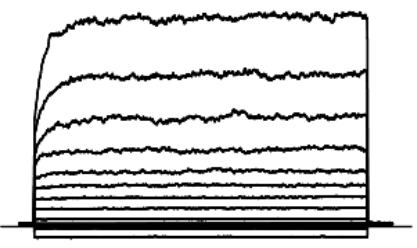

Chl-T

Figure 1. Application of Chl-T activates large outward currents in IGR39 cells, but not in IGR37 cells. (a) Left: time course of currents elicited in a typical IGR39 cell during the application of 0.5 $\mathrm{mM}$ Chl-T in STD solution, at different potentials from $-100 \mathrm{mV}$ to $+100 \mathrm{mV}$, as indicated. Right: IV relationship in the same IGR39 cell elicited before and after the addition of Chl-T. (b) Similar to (a), but recorded in a representative IGR37 cell.

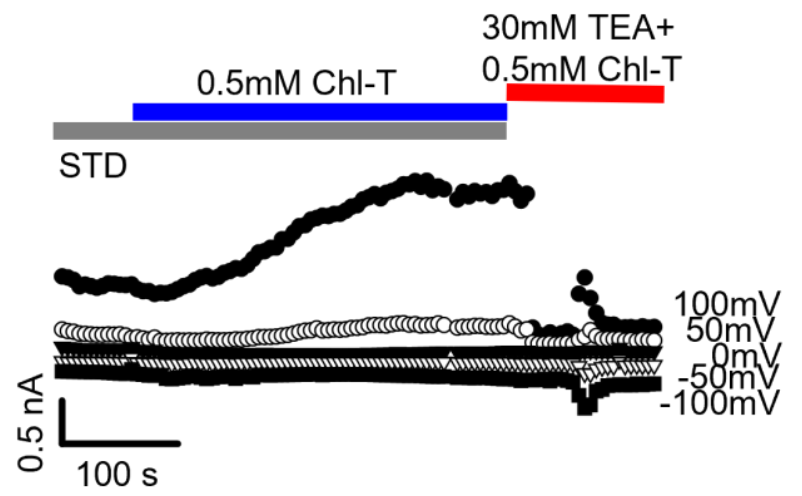

Figure 2. TEA blocks Chl-T-evoked outward currents. The figure shows a representative recording in which the addition of $30 \mathrm{mM}$ TEA almost completely ( 75\%) inhibited currents elicited by the application of $0.5 \mathrm{mM}$ Chl-T.

It is known that IGR39 cells express the large-conductance $\mathrm{Ca}^{2+}$-activated BK channel $[53,54]$, and that these channels are activated by Chl-T [16]. In addition, BK channels are sensitive to the presence of TEA [55]. These results suggested that Chl-T-activated currents could be predominantly carried by BK channels. To confirm this hypothesis, we employed the specific BK inhibitor paxilline [56]. As observed for TEA, $1 \mu \mathrm{M}$ paxilline also reduced the Chl-T-activated current by $\sim 80 \%$ (Figure 3 ). 
a

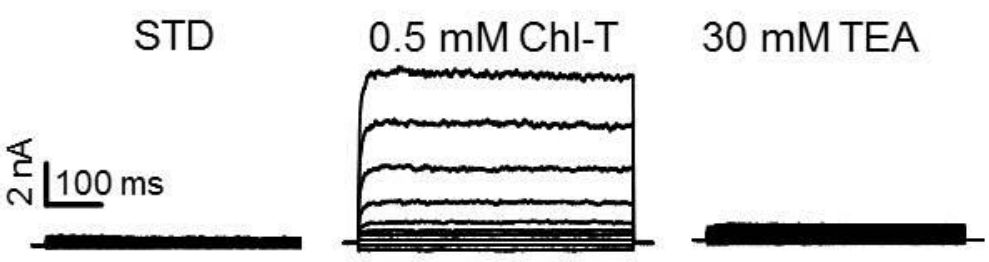

b

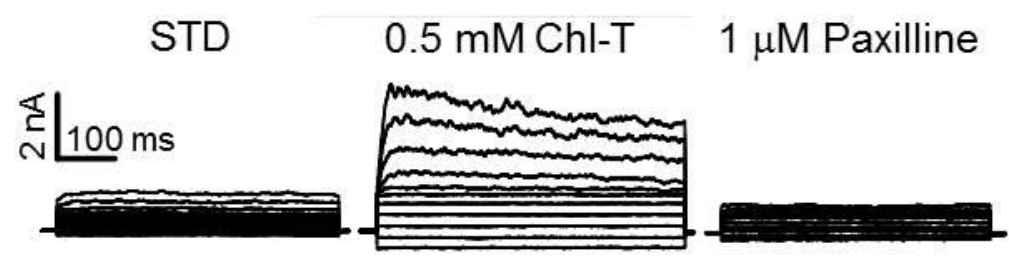

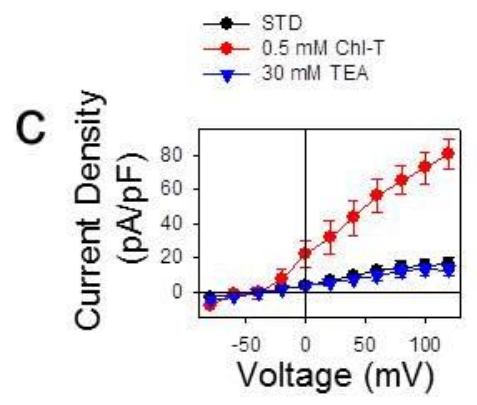

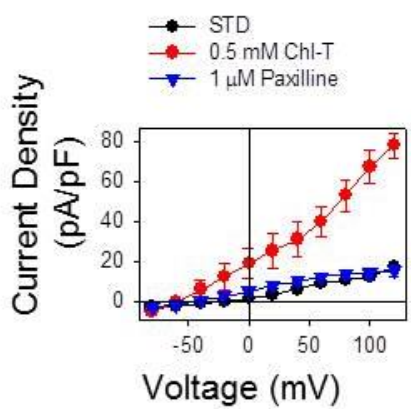

Figure 3. BK current activation by Chl-T oxidation in IGR39 cells. (a) Currents in a typical IGR39 cell elicited in STD solution (left) and after addition of $0.5 \mathrm{mM}$ Chl-T (middle). Chl-T-evoked currents were blocked by $30 \mathrm{mM}$ TEA (right traces). Average block at $100 \mathrm{mV}: 81.9 \pm 3.7 \%(p=0.017, n=8)$. (b) Representative currents recorded from another IGR39 cell. The potassium current, stimulated by oxidation, was blocked at positive voltages by $1 \mu \mathrm{M}$ paxilline (right panel). Average block at $100 \mathrm{mV}: 79.0 \pm 2.5 \%(p=0.0062, n=6)$. (c) Average current density-voltage relationships for IGR39 cells treated with Chl-T and $30 \mathrm{mM}$ TEA (top panel) and Chl-T and $1 \mu \mathrm{M}$ paxilline (bottom). Data are expressed as mean $\pm \mathrm{SEM}$ from 6 experiments each.

\subsection{Additional TEA- and Paxilline-Insensitive $\mathrm{K}^{+}$Current Activated by Chl-T}

Closer inspection of KROS currents suggested the potential presence of a voltageindependent component (see, for example, the middle traces in Figure 3b), which appeared not to be completely inhibited by paxilline, and thus probably not mediated by BK. Therefore, we performed new experiments using an extracellular solution, in which the concentration of $\mathrm{NaCl}$ was further reduced to $60 \mathrm{mM}$ in order to decrease any possible contamination by sodium conductances. To keep the osmolarity constant, $\mathrm{NaCl}$ was replaced with mannitol (ISO-TEA, see Table 1). Perfusion with ISO-TEA inhibited the initially dominant $\mathrm{K}^{+}$conductance, most likely carried by BK channels (Figure 4a). Subsequent application of Chl-T activated significant inward and outward currents, with a reversal potential of about $-55.5 \pm 0.7 \mathrm{mV}(n=25)$-relatively close to that of a current being predominantly carried by $\mathrm{K}^{+}$(Figure $4 \mathrm{a}$ ). The effect of paxilline on the current activated by Chl-T was less pronounced at negative potentials, supporting the hypothesis that $\mathrm{Chl}-\mathrm{T}$ also stimulates $\mathrm{K}^{+}$conductances insensitive to both TEA and paxilline, and thus different from BK channels. In fact, at $-80 \mathrm{mV}$, paxilline inhibited Chl-T-evoked currents by only $28 \pm 12 \%(p=0.037, n=6)$ (data not shown).

Several members of the K2P channel family are insensitive to TEA but sensitive to oxidizing conditions [57-59]. Thus, in order to determine which ion channel(s) underlie the observed current, we transfected TASK2, TREK1, TREK2, and TALK2 channels in HEK293 cells, and tested their sensitivity to Chl-T. However, none of these channels were significantly activated (Figure S2a-d).

Next, analysis of publicly available gene expression datasets of IGR39 and IGR37 cells revealed that the medium-conductance, $\mathrm{Ca}^{2+}$-activated, TEA-insensitive, voltageindependent channel gene KCNN4 [60] is significantly more expressed in IGR39 than IGR37 cells (Figure 4b, Table S2). To test whether the KCNN4-encoded KCa3.1 channel underlies the TEA-insensitive component activated by Chl-T, we applied the specific KCa3.1 blocker senicapoc (bis(4-fluorophenyl)phenyl acetamide), which has a reported 
$\mathrm{IC}_{50}$ of $11 \mathrm{nM}$ [61-63]. Figure 4c illustrates that $50 \mathrm{nM}$ senicapoc clearly inhibited currents evoked by Chl-T in the presence of TEA. The reduction of the activated current was $65 \pm 7 \%$ $\left(p=8.7 \times 10^{-5}, n=4\right)$, demonstrating that the TEA-insensitive and voltage-independent components are indeed carried by KCa3.1 channels.
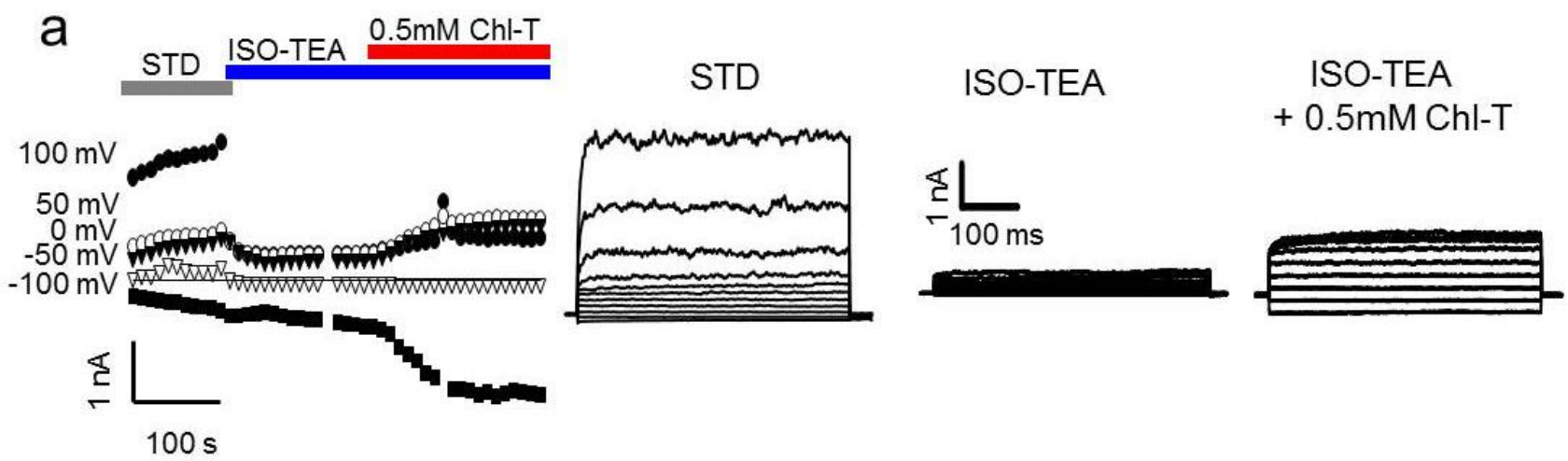

b

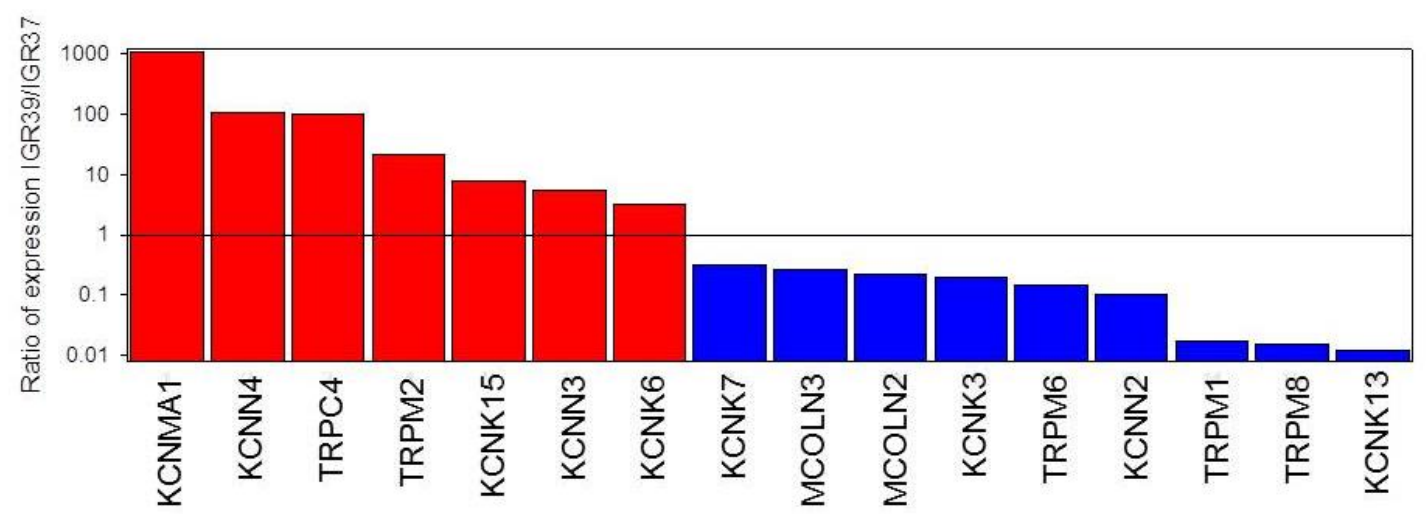

C

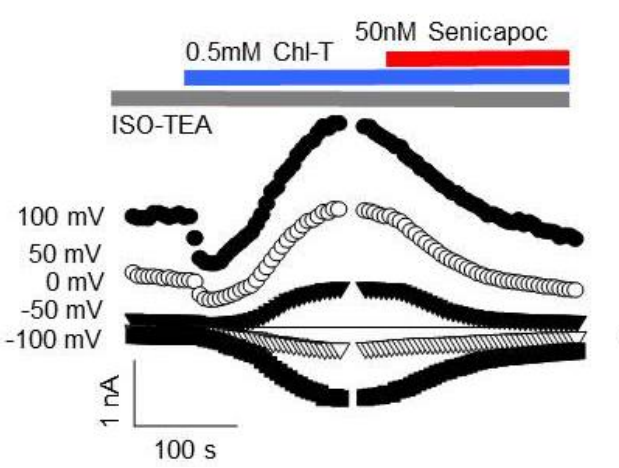

ISO-TEA

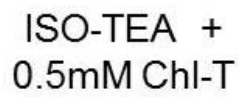
ISO-TEA + 0.5mM Chl-T $+50 \mathrm{nM}$ Senicapoc

Figure 4. (a) Activation of TEA-insensitive current component by Chl-T. Right: time course of currents elicited in a representative IGR39 cell. Application of the ISO-TEA solution (blue bar) inhibited constitutively active BK-mediated currents. Subsequent addition of $0.5 \mathrm{mM}$ Chl-T activated a significant current component. Left: IV relationships in the indicated conditions. (b) Comparative gene expression analysis of $\mathrm{K}^{+}$and TRP ion channel genes in IGR39 vs. IGR37 cells. As expected, KCNMA1 was highly expressed in IGR39 compared to IGR37 cells. Among other Ca ${ }^{2+}$-activated $\mathrm{K}^{+}$channels, KCNN4-encoded KCa3.1 is more expressed in IGR39 cells, and among TRP channels, TRPC4 and TRPM2 are significantly more expressed in IGR39 cells. The analysis is based on the GSE137391 dataset, as described in the Materials and Methods section. The plot shows only genes with fold change $>2$ (see also Table S2). The TRPA1 channel that has been reported to be activated by $0.1 \mathrm{mM}$ Chl-T [64] is weakly expressed in both cell lines, and 1.6-fold more in IGR37 compared to IGR39 cells. (c) Inhibition of the TEA-insensitive component by senicapoc. Right: time course of currents elicited in a representative IGR39 cell kept initially in ISO-TEA, and then exposed to $0.5 \mathrm{mM}$ Chl-T in ISO-TEA. Addition of $50 \mathrm{nM}$ senicapoc-a specific inhibitor of KCa3.1-led to an immediate block of the TEA-insensitive potassium current. Left: IV relationships in the indicated conditions. 


\subsection{Intracellular $\mathrm{Ca}^{2+}$ Increase by the Application of Chl-T}

To test for possible mechanisms underlying the activation of both $\mathrm{Ca}^{2+}$-sensitive $\mathrm{K}^{+}$ channels (BK and KCa3.1), we employed fura-2 $\mathrm{Ca}^{2+}$ imaging. The application of $\mathrm{Chl}-\mathrm{T}$ indeed induced a dramatic increase of $\left[\mathrm{Ca}^{2+}\right]_{i}$ to $\sim 800 \mathrm{nM}$ (Figure 5a). The $\mathrm{Ca}^{2+}$ increase was completely dependent on the influx of extracellular $\mathrm{Ca}^{2+}:\left[\mathrm{Ca}^{2+}\right]_{i}$ did not increase when a bath solution without added $\mathrm{Ca}^{2+}$ and with 3 mM EGTA (STD $0 \mathrm{Ca}^{2+}$ ) was applied (Figure $5 b$ ), suggesting that $\mathrm{Chl}-\mathrm{T}$ activates a plasma-membrane-localized $\mathrm{Ca}^{2+}$-permeable channel. No $\mathrm{Ca}^{2+}$ increase could be detected in IGR37 cells upon the application of Chl-T (Figure S1).
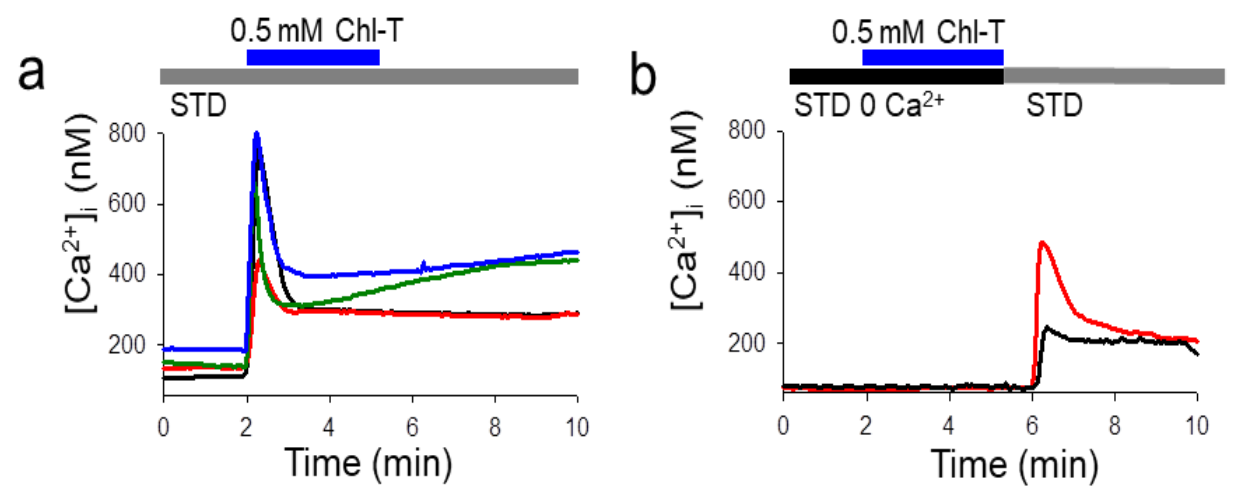

Figure 5. Application of Chl-T increases intracellular $\mathrm{Ca}^{2+}$ concentration. (a) Representative recordings of $\left[\mathrm{Ca}^{2+}\right]_{i}$ in different IGR39 cells obtained from different cell preparations after the application of $0.5 \mathrm{mM} \mathrm{Chl}-\mathrm{T}$ in the standard bath solution containing $2 \mathrm{mM} \mathrm{Ca}^{2+}\left(\Delta\left[\mathrm{Ca}^{2+}\right]_{\mathrm{i}}=640 \pm 30 \mathrm{nM}(24\right.$ cells $\left.)\right)$. (b) Similar experiments obtained in the absence of $\mathrm{Ca}^{2+}$ in the external solution. Intracellular $\mathrm{Ca}^{2+}$ increase was observed only when $\mathrm{Ca}^{2+}$ was added to the bath solution. Horizontal bars indicate the time period of exposure. Note that in zero external calcium the resting cytosolic calcium is lower. Average resting values were $127 \pm 9 \mathrm{nM}$ in STD and $75 \pm 2 \mathrm{nM}$ without external calcium.

To further test the role of $\mathrm{Ca}^{2+}$ influx as the trigger of $\mathrm{BK}$ and $\mathrm{KCa} 3.1$ channel activation, we measured the current response to Chl- $\mathrm{T}$ in the absence of extracellular $\mathrm{Ca}^{2+}$. Under these conditions, the application of the oxidizing agent did not activate any significant current, until the extracellular solution was replaced by the $\mathrm{Ca}^{2+}$-containing STD solution (Figure 6).

This observation led us to hypothesize that Chl-T does not act directly on BK and KCa3.1 channels, but that it oxidizes and activates an unidentified $\mathrm{Ca}^{2+}$-permeable channel, whose activation induces an increase in intracellular $\mathrm{Ca}^{2+}$ and the consequent activation of the two $\mathrm{Ca}^{2+}$-activated potassium channels.

\subsection{Identification of a Plasma Membrane $\mathrm{Ca}^{2+}$-Permeable Channel Sensitive to Oxidation}

From the gene expression analysis shown in Figure $4 \mathrm{~b}$, two $\mathrm{Ca}^{2+}$-permeable channels stand out as being more highly expressed in IGR39 vs. IGR37 cells: TRPC4 and TRPM2. We focused on TRPM2 because it is known to be activated by oxidation [65]. We performed $\mathrm{Ca}^{2+}$ imaging with fura-2-AM and patch-clamp experiments, and employed two TRMP2 inhibitors@ ACA (N-(p-amylcinnamoyl)anthranilic acid) and 1-(o-chloro$\alpha, \alpha$-diphenylbenzyl)imidazole (clotrimazole) [65-67]. The administration of Chl-T in the presence of ACA or clotrimazole prevented the activation of $\mathrm{K}^{+}$currents in whole-cell recordings (Figure 7a,b). Similarly, the presence of ACA almost completely impeded the $\mathrm{Ca}^{2+}$ influx in IGR39 cells induced by Chl-T $\left(\left[\mathrm{Ca}^{2+}\right]_{\mathrm{i}}\right.$ increase: $15 \pm 4 \mathrm{nM}(n=35)$, much smaller than in the absence of ACA, Figure 7c). Unfortunately, clotrimazole is able to release $\mathrm{Ca}^{2+}$ from the endoplasmic reticulum [68], making measurements using this inhibitor problematic (data not shown). 


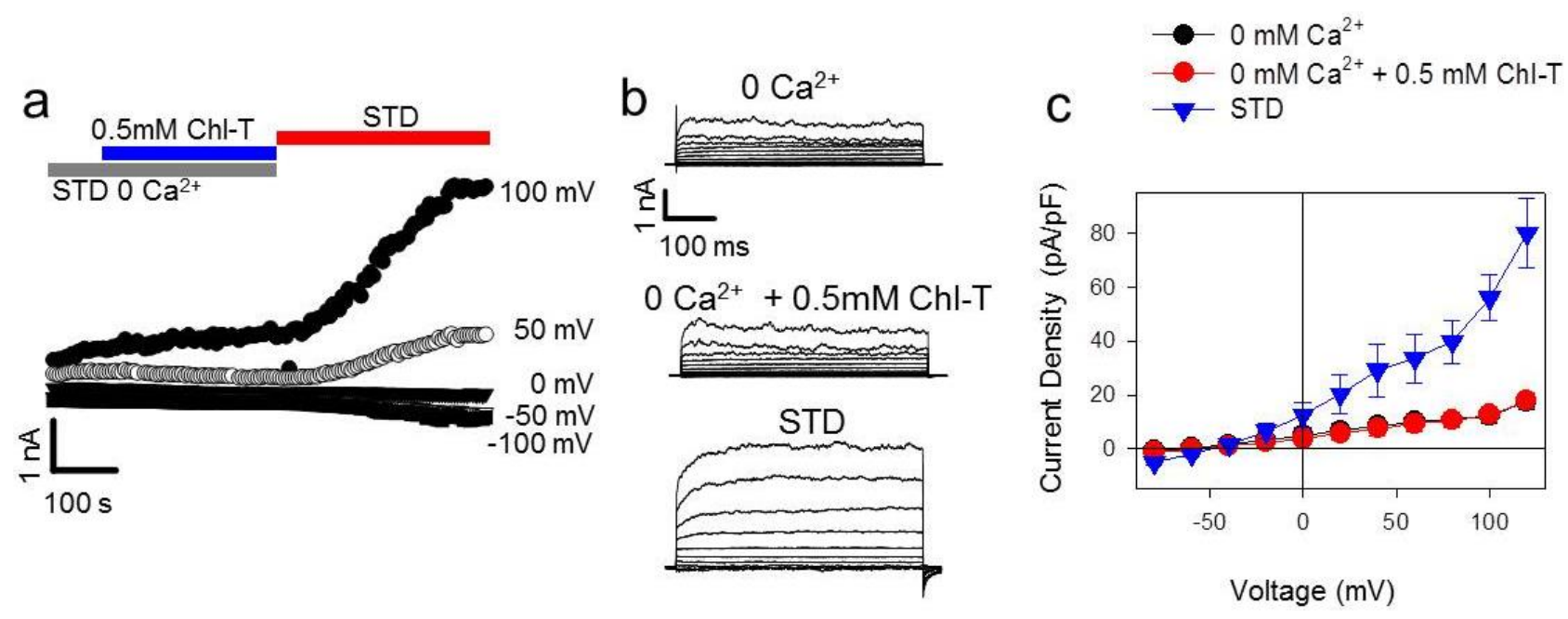

Figure 6. Application of Chl-T in the absence of extracellular $\mathrm{Ca}^{2+}$ does not activate $\mathrm{K}^{+}$currents in IGR39 cells. (a) Time course of currents elicited in a representative IGR39 cell during the application of $0.5 \mathrm{mM} \mathrm{Chl}-\mathrm{T}$ in $0-\mathrm{Ca}^{2+}$ solution and subsequent application of STD solution. (b) Current traces before Chl-T application (left), during application in $0 \mathrm{Ca}^{2+}$ (middle), and after perfusion with STD solution (right) (normalized Chl-T response in STD $0 \mathrm{Ca}^{2+}$ solution at $100 \mathrm{mV}=1.08 \pm 0.04, p=0.7, n=5$; current fold increase after STD application $2.02 \pm 0.22, p=0.004, n=4)(\mathbf{c})$ Current density-voltage relationship for IGR39 cells after the application of Chl-T in the absence of extracellular $\mathrm{Ca}^{2+}$, and subsequent STD administration. Data are expressed as mean \pm SEM from 5 independent experiments. Vhold $=-50 \mathrm{mV}$.

a

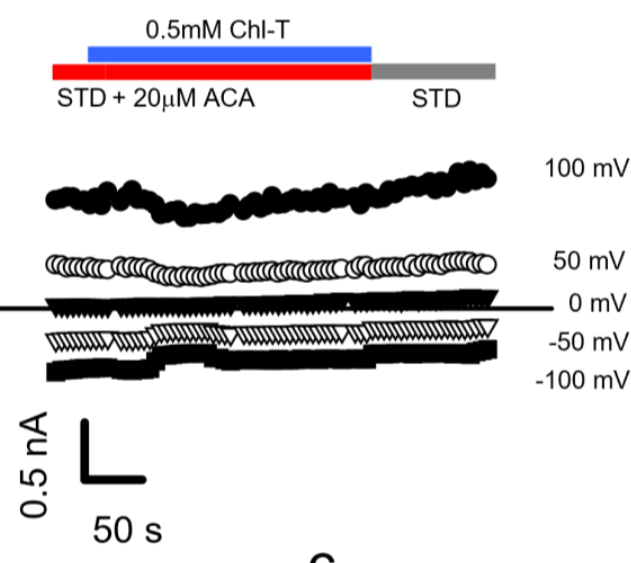

b
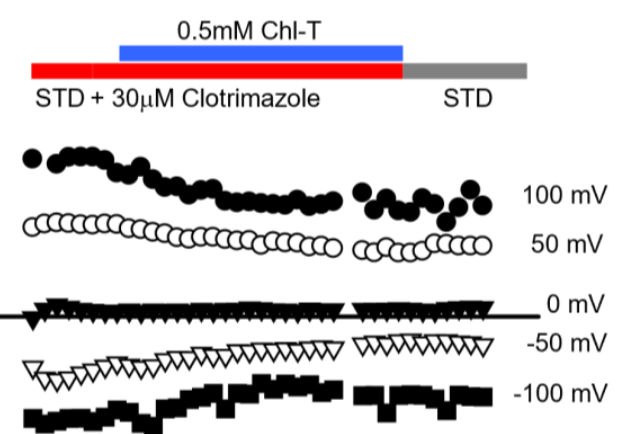

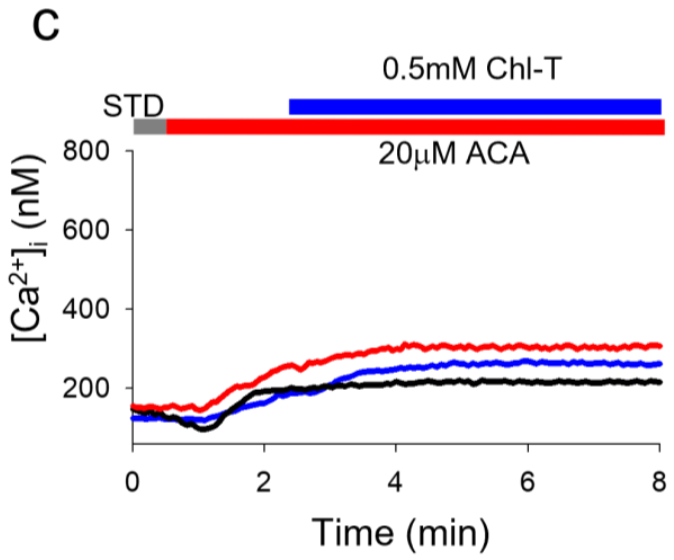

Figure 7. In IGR39 cells, TRPM2 blockers ACA and clotrimazole impede $\mathrm{K}^{+}$current activation and [Ca $\left.{ }^{2+}\right] \mathrm{i}$ increase by Chl-T. (a) Time course of currents recorded in a representative IGR39 cell during application in bath solution containing $0.5 \mathrm{mM}$ ChlT and $20 \mu \mathrm{M}$ ACA. (b) Similar to panel (a), but recorded during the addition of $30 \mu \mathrm{M}$ clotrimazole. (c) Representative traces of $\left[\mathrm{Ca}^{2+}\right]$ i recorded in IGR39 cells after the application of $0.5 \mathrm{mM}$ Chl-T with $20 \mu \mathrm{M}$ ACA in the standard bath solution containing $2 \mathrm{mM} \mathrm{Ca}^{2+}$. 
To further test the hypothesis that Chl-T activates TRPM2, leading to $\mathrm{Ca}^{2+}$ influx, we expressed human TRPM2 in HEK293 cells and performed $\mathrm{Ca}^{2+}$ imaging and patchclamp experiments. The application of $0.5 \mathrm{mM}$ Chl-T had no effect in non-transfected cells (Figure 8a), but induced a significant increase in currents in TRPM2-transfected cells (Figure $8 \mathrm{~b}, \mathrm{c}$ ), which was reversed by $20 \mu \mathrm{M}$ ACA (Figure $8 \mathrm{~b}$ ) or $30 \mu \mathrm{M}$ clotrimazole (Figure 8c)—specific TRMP2 inhibitors. Thus, we conclude that Chl-T activates TRPM2, leading to $\mathrm{Ca}^{2+}$ influx and consequent activation of both BK and KCa3.1 channels.

a

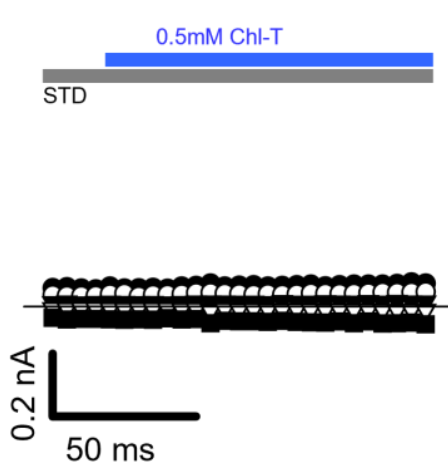

b

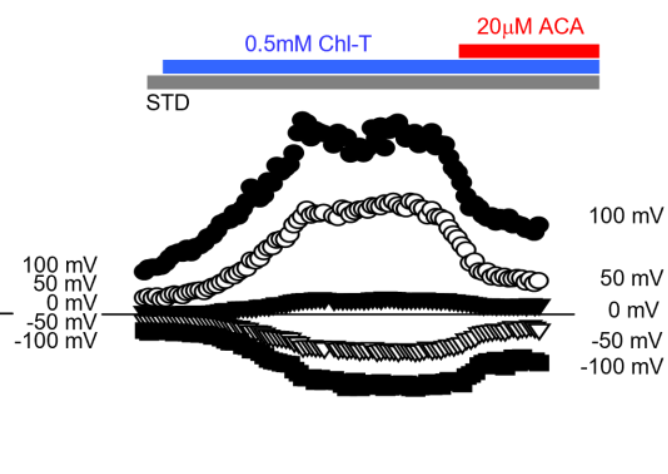

C

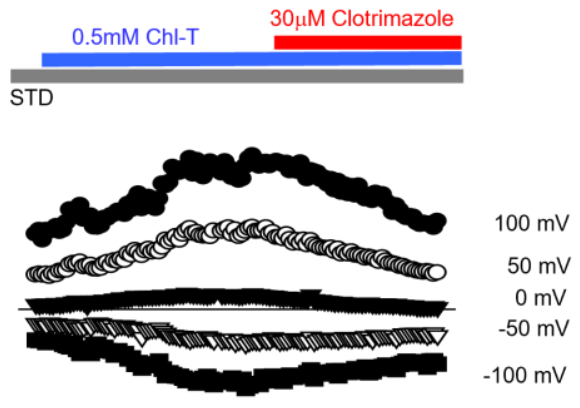

Figure 8. Activation of heterologously expressed TRMP2 by Chl-T. (a) Time course of currents elicited in an HEK-null cell during the addition of $0.5 \mathrm{mM}$ ChlT in STD solution. $(\mathbf{b}, \mathbf{c})$ Time course of currents recorded in two representative transfected HEK293 cells during the application of $0.5 \mathrm{mM}$ ChlT and subsequent addition of $20 \mu \mathrm{M}$ ACA (b) or $30 \mu \mathrm{M}$ clotrimazole (c). Normalized current increase at $100 \mathrm{mV}: 2.18 \pm 0.39, p=0.007, n=11$. Average ACA block at $100 \mathrm{mV}: 55.89 \pm 1.92 \%$ $(p=0.00006, n=4)$, and average clotrimazole block at $100 \mathrm{mV}: 29.48 \pm 1.97(p=0.0007, n=4)$.

\subsection{Application of the Oxidizing Agent TBH70X Does Not Activate KROS}

To test whether oxidation-mediated activation of KROS is specific to Chl-T, we applied TBH70X - another widely used oxidizing agent. Surprisingly, the application of $1 \mathrm{mM}$ TBH70X to IGR39 cells did not elicit any current increase in three different experiments (Figure 9a,b). Similarly, TBH70X did not increase $\left[\mathrm{Ca}^{2+}\right]_{\mathrm{i}}$ (Figure $\left.9 \mathrm{~b}\right)\left(\left[\mathrm{Ca}^{2+}\right]_{\mathrm{i}}\right.$ increase: $13 \pm 7 \mathrm{nM}(n=18))$.

a

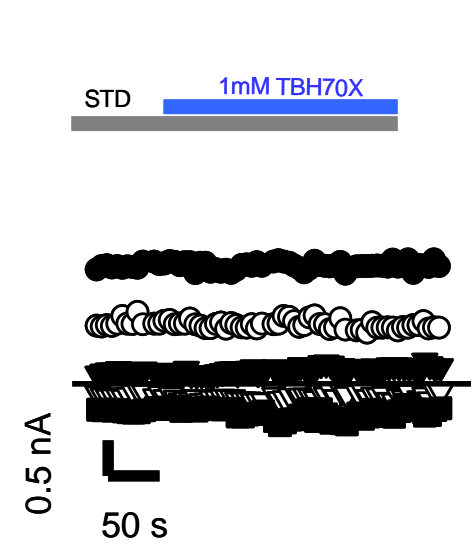

b

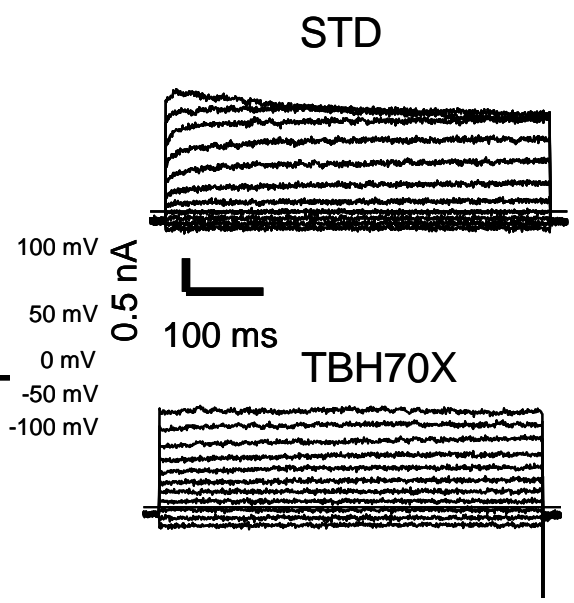

C

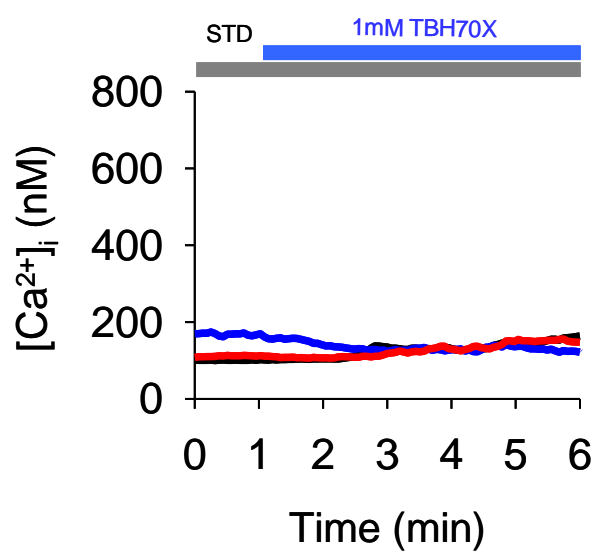

Figure 9. Application of TBH70X does not activate currents in IGR39 cells. (a) Time course of currents elicited in an IGR39 cell during the application of $1 \mathrm{mM}$ TBH70X in STD solution, at different potentials from $-100 \mathrm{mV}$ to $+100 \mathrm{mV}$, as indicated. (b) Representative current recorded in the same IGR39 cell elicited before and after the addition of 1 mM TBH70X. (c) Representative traces of $\left[\mathrm{Ca}^{2+}\right] \mathrm{i}$ after the application of $1 \mathrm{mM}$ TBH70X in the standard bath solution containing $2 \mathrm{mM} \mathrm{Ca}^{2+}$. 


\subsection{Channel Gene Expression Analysis}

We performed quantitative real-time PCR experiments for a selected number of genes to confirm the gene expression data from the literature. In the first round, we screened all members of the family of $\mathrm{K} 2 \mathrm{P}$ channels, which are voltage-independent and TEAinsensitive $\mathrm{K}^{+}$channels and, thus, putative targets of the Chl-T response in IGR39 cells. Interestingly, one member of the family-KCNK2 (TREK1)—showed higher expression in IGR39 than IGR37 cells (Figure S3). However, in absolute terms, TREK1 expression is relatively low in IGR39 cells. Furthermore, as shown in Figure S2, TREK1 is insensitive to Chl-T. Moreover, KCNK7 was rather highly transcribed in both cell lines, consistent with data on human melanoma samples [69]. However, it is known from the literature that its expression does not give rise to any functional channel [70]. Consistent with this, we could not detect any channel activity in HEK cells transfected with a KCNK7 plasmid, and Chl-T did not activate any $\mathrm{K}^{+}$currents (data not shown).

Our qPCR analysis indicated that the expression of KCNMA1, encoding the alpha subunit of BK, was 1400-fold higher in IGR39 cells compared to their metastatic counterpart IGR37 (Figure 10), confirming the results from public datasets and from our functional analysis. TRPM2 and KCNN4 were also more expressed in IGR39 than IGR37 cells (Figure 10).

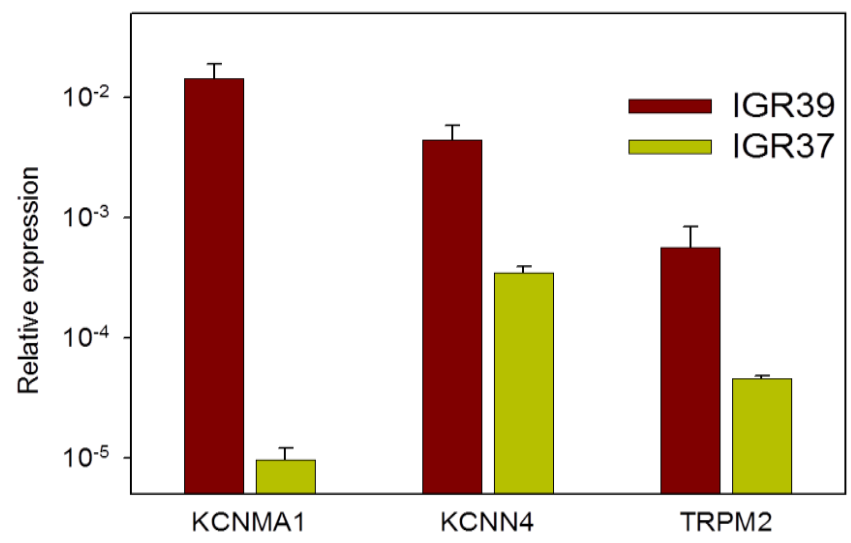

Figure 10. Expression of KCNMA1, TRPM2, and KCNN4 in primary and metastatic melanoma cell lines. Expression is relative to that of the housekeeping genes actin or GAPDH $(n=2-3$ experiments, each run in triplicate; see Materials and Methods).

In order to test whether the high expression and functionality of KCNMA1, KCNN4, and TRPM2 is specific to (primary) IGR39 cells, we analyzed several publicly available datasets on gene expression in melanocytes, as well as primary and metastatic melanoma cell lines (Figure 11). Interestingly, while, as expected, melanocytes (adult and neonatal) showed little expression of these three genes, but high expression of TRPM1 (Figure 11, first row), all primary melanoma lines-including IGR39-showed a decreased expression of TRPM1 and highly increased expression of KCNMA1 and TRPM2, and also of KCNN4 in three out of four (Figure 11, second row). On the other hand, several metastatic lines-including IGR37-regained significant expression of TRPM1 and showed reduced expression of KCNMA1, KCNN4, and TRPM2, compared to the primary melanoma lines (Figure 11, third row). Other metastatic lines showed an intermediate expression pattern (Figure 11, fourth row). 


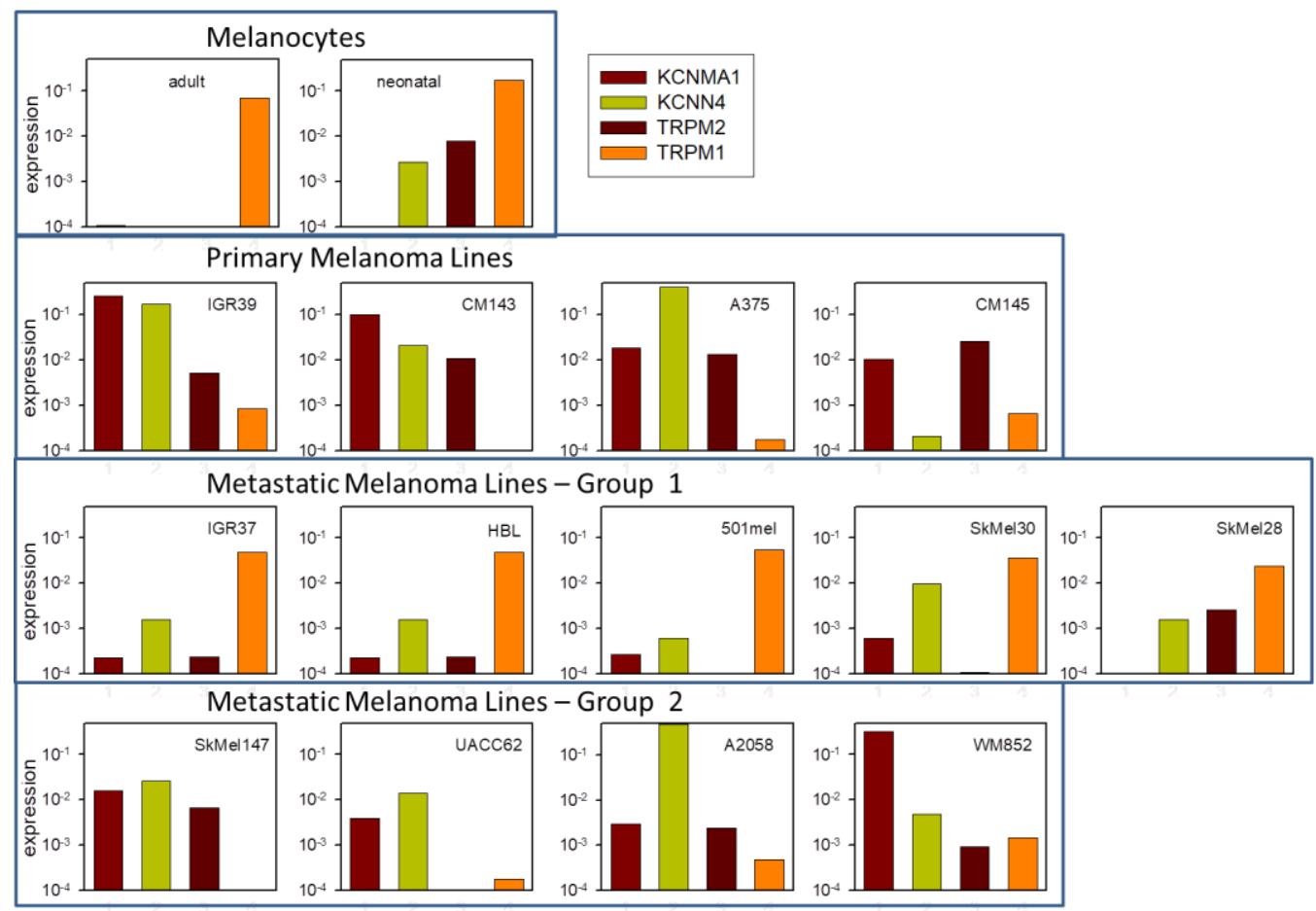

Figure 11. Expression analysis of selected ion channel genes in melanoma. Expression of the KCNMA1, KCNN4, TRPM2, and TRPM1 genes in the indicated cell lines, as described in the Materials and Methods section.

\section{Discussion and Conclusions}

Oxidative stress reflects the imbalance between elevated ROS levels and the ability of the endogenous antioxidant system to readily detoxify the reactive intermediates or to repair cellular damage [71]. Most vulnerable to free radical attack is the cell membrane, as it contains a wide range of ion channels and other membrane proteins able to elicit different cellular reactions in response to extracellular stimuli and stressors. Therefore, the aim of the present study was to investigate the effects of the oxidizing reagent Chl-T on plasma membrane ion channel activity in primary (IGR39) and metastatic (IGR37) melanoma cells.

Based on a series of experiments, we could conclude that Chl-T activates the calciumpermeable TRPM2 channel, which is known to be sensitive to oxidation [42]. TRPM2 activation causes a dramatic increase in $\left[\mathrm{Ca}^{2+}\right]_{\mathrm{i}}$, which stimulates two distinct $\mathrm{Ca}^{2+}$-dependent $\mathrm{K}^{+}$channels in IGR39 cells: the large-conductance voltage-dependent $\mathrm{BK}$ channel encoded by KCNMA1, and the medium-conductance voltage-independent KCa3.1 channel encoded by KCNN4.

To identify the elements involved in Chl-T-induced $\left[\mathrm{Ca}^{2+}\right]_{i}$ increase and KROS activation-and, thus, to clarify the underlying molecular mechanism-we employed several pharmacological inhibitors: paxilline for BK channels, senicapoc for KCa3.1 channels, and clotrimazole and ACA for TRPM2 channels. Paxilline and senicapoc are rather specific for their targets among $\mathrm{K}^{+}$channels [56,61-63]. Neither ACA nor clotrimazole are highly specific for TRPM2 [72]. For example, clotrimazole has been shown to activate the TRPA1 and TRPV1 channels [73]. Furthermore, ACA can act on several TRP channels, in the order TRPM2, TRPM8 > TRPC6 > TRPC3 [67,74,75]. Nevertheless, TRPM8, TRP6, and TRPC 3 are little-expressed in IGR39 cells, and ACA does not appear to be effective on TRPC4 [76], which is instead highly expressed in IGR39 (see Figure 4b). In addition, the fact that both compounds-ACA and clotrimazole-inhibit Chl-T-induced KROS activation, and ACA blocks Chl-T-dependent $\left[\mathrm{Ca}^{2+}\right]_{\mathrm{i}}$ increase, strongly argues in favor of the hypothesis that oxidation of TRPM2 underlies the effects. Furthermore, the predominant role of TRPM2 was confirmed by showing that heterologously expressed TRPM2 was activated by Chl-T in HEK293 cells assayed by electrophysiology. Moreover, these conclusions were 
fully confirmed by PCR-based gene expression analysis of KCNMA1, KCNN4, and TRPM2, in perfect agreement with publicly available gene expression datasets (Figures 10 and 11). Strictly, gene expression analysis does not prove that the respective proteins are expressed at an equivalent level. Complementary assays-for example, siRNA-mediated interference or Western blot-can provide additional evidence. For KCNMA1 and KCNN4, our functional and pharmacological evidence leaves little doubt of their strong expression in IGR39 cells, as also established by previous works $[28,53,54]$. In preliminary experiments, we tested the transfection of IGR39 cells via GFP-encoding plasmids, and found an extremely low transfection efficiency (data not shown). This renders the siRNA interference approach unfeasible. Furthermore, for TRPM2, no reliable antibodies are available. In any case, the combined evidence provided by electrophysiological, pharmacological, and gene expression analysis strongly suggests a significant expression of TRPM2 in IGR39 cells, and a weak expression in IGR37 cells.

It will be interesting to test whether the activation of TRPM2 is mediated by the oxidation of methionine 214 that has been identified as the target of $\mathrm{H}_{2} \mathrm{O}_{2}$-induced activation [77]. Conversely, the metastatic cell line IGR37, obtained from the same patient as the IGR39 cells, had a completely different behavior: no currents were activated upon Chl-T application, and no increase in intracellular $\mathrm{Ca}^{2+}$ levels could be detected (Figure S1). Again, the low expression of the three genes KCNMA1, KCNN4, and TRPM2 is in agreement with these findings. To test for the specificity of the action of Chl-T in IGR39 cells, we tested TBH70X - commonly used to model in vitro oxidant conditions - as it easily permeates the plasma membrane. Similarly to $\mathrm{H}_{2} \mathrm{O}_{2}, \mathrm{TBH} 70$ X promotes $\mathrm{OH}^{\bullet}$ radical formation via interaction with transition metals, usually present inside the cell, leading to subsequent cell injury [78]. Interestingly, TBH70X evoked neither BK channel activation nor an increase in $\left[\mathrm{Ca}^{2+}\right]_{i}$ in IGR39 cells (Figure 9), confirming the specificity of Chl-T. Similarly, volumeregulated anion channels composed of LRRC8A and LRRC8C subunits are inhibited by Chl-T but not TBH70X [79], which could be explained by the hypothesis that methionines are the target of Chl-T, in that TBH70X is less efficient than Chl-T in oxidizing methionines compared-for example-to cysteines.

Interestingly, the application of Chl-T at elevated concentrations in inside-out patches leads to BK channel activation via a direct oxidation of intracellular methionines [16,80]. These findings are not consistent with our results in IGR39 cells, as Chl-T exposure in the absence of extracellular $\mathrm{Ca}^{2}$ did not impact BK currents in our experiments, thus indicating that a direct interaction between Chl-T and BK is unlikely to occur. The use of a low concentration and its application from the extracellular side are probably not sufficient to oxidize the intracellular methionines.

An important question is whether our conclusions are limited to IGR39 cells, or whether they could have more widespread relevance for other types of melanoma. The in silico gene expression analysis shown in Figure 11 strongly suggests that not only KCNMA1 is highly expressed in primary melanoma cells, as already known [81], but also KCNN4 and TRPM2. Conversely, several metastatic melanoma lines (including IGR37) neither express KCNMA1 nor KCNN4 or TRPM2 in a significant manner, but regain a significant expression levels of TRPM1, while other metastatic lines are similar to primary melanoma (Figure 11). This observation is in line with the great heterogeneity of metastases [82].

The importance of oxidation-induced $\left[\mathrm{Ca}^{2+}\right]_{\mathrm{i}}$ increase and KROS activation may not be limited to melanoma. In proof-of-principle experiments, we investigated the effects of Chl-T in a primary tumor cell line from pancreatic duct cancer-namely, Panc-1. As illustrated in Figure S4a, stimulation of Panc-1 cells with $0.5 \mathrm{mM}$ Chl-T evoked a large $\mathrm{K}^{+}$current, with a 10-fold increase at $100 \mathrm{mV}$ compared to the initial current. This Chl-Tinduced current appeared to be very similar in terms of kinetics and voltage dependence to those we measured in Panc-1 cells when we employed the well-known BK activator NS-11021 (Figure S4b). Moreover, two independent RT-qPCR assays revealed that the BK channel is also expressed in this cell type (data not shown). The BK activation caused by 
Chl-T in Panc- 1 cells is consistent with what Lin et al. demonstrated on the expression and role of TRPM2 in the proliferation and invasion of pancreatic ductal adenocarcinoma [83].

It is tempting to speculate that the KCNMA1, KCNN4, and TRPM2 genes are functionally important for melanoma development, and can be pharmacological targets with metastatic potential. In fact, the BK channel has already been investigated as a target of cancer therapeutic drugs, although its role is very complex, and may not be universal $[25,27,49,50,84-87]$. Accumulating evidence has demonstrated that BK channels are overexpressed in some tumors compared with their healthy counterparts, thus playing a crucial role in controlling the cell cycle, cell proliferation, invasion, and metastasis $[26,86,88]$. In this regard, many of the pathophysiological phenotypes are associated with the upregulation of BK channels, confirming that the inhibition of BK channels might act as antitumor factor. In addition, the increased expression of KCNMA1 in melanoma has been linked to the miRNA miR-211, which is encoded by intron 6 of TRPM1, and whose expression is inversely correlated with that of KCNMA1 in primary melanoma cell lines and melanoma samples from patients [81]. It would be interesting to find out whether the expression of KCNN4 and TRPM2 is similarly linked to miR-211.

The oxidation sensitivity of TRPM2 is also particularly intriguing, and might be important in the tumor environment characterized by increased oxidative stress. Two basic cellular parameters could play a role in relation to these three ion channels: First, the dynamics of $\left[\mathrm{Ca}^{2+}\right]_{i}$ influence myriad metabolic and signaling processes, including proliferation, gene expression, and migration. The activation of $\mathrm{K}^{+}$channels tends to hyperpolarize the membrane potential, which can have direct, mostly inhibitory, effects on mitosis. In addition, a negative membrane potential increases the driving force for $\mathrm{Ca}^{2+}$ influx. In addition, KCa3.1 has been specifically involved in migration of melanoma cells [89].

In a similar manner, targeting KCa3.1 channels has been proposed as a strategy for pharmacological intervention in glioblastoma [90], in that the channel is also highly expressed and of likely importance in that tumor [91]. From a practical point of view, as highlighted by Brown et al. [90], senicapoc has already been tested in Phase III clinical trials, and would therefore be available for repurposing. It will be important in future research to uncover the specific functional roles of these ion channels in melanoma. Deciphering their roles will help in devising specific pharmacological tools targeting these three genes, aimed at interfering in melanoma expansion and metastasis. Nevertheless, it cannot be fully ruled out that the expression of the KCNMA1, KCNN4, and TRPM2 genes in melanoma may be an epiphenomenon, i.e., unrelated to the tumor biology. However, even in this case, the widespread expression of these genes in primary and several metastatic melanomas could be considered to be an Achilles heel that can be exploited in drug treatment accompanying classical approaches. For example, activators of these channels could exacerbate the $\mathrm{Ca}^{2+}$ increase and promote apoptosis.

In conclusion, the high expression of the genes encoding for these ion channels in melanoma cells, together with their functional interrelation and concomitant activation by the oxidative conditions shown here, provides a promising route for pharmacological treatment. Specifically, targeting one or more of these channels could dramatically increase the effectiveness of classical treatments such as radio- or chemotherapy. This therapeutic strategy appears particular interesting, since melanoma is incurable when metastatic. Thus, this study could offer a good basis for the understanding of the relationship between oxidative stress and ion channels in melanoma. However, further investigations will be required in order to better clarify the involvement of these channels in tumorigenic events, such as cell viability, cell proliferation, and migration.

\section{Materials and Methods}

\subsection{Cell Culture}

The primary melanoma cell line IGR39, along with metastatic IGR37 cells, were obtained from Deutsche Sammlung von Mikroorganismen und Zellkulturen GmbH. They 
were derived from the same patient, and were cultured in DMEM medium, supplemented with $10 \%$ fetal calf serum, $2 \mathrm{mM}$ L-glutamine, $100 \mu / \mathrm{mL}$ penicillin, $100 \mu \mathrm{g} / \mathrm{mL}$ streptomycin, $1 \%$ vitamin mix, and 1\% non-essential amino acids. The HEK293 cell line was cultured in DMEM medium, supplemented with 10\% fetal calf serum, $2 \mathrm{mM}$ L-glutamine, $100 \mu / \mathrm{mL}$ penicillin, and $100 \mu \mathrm{g} / \mathrm{mL}$ streptomycin. All cell lines were maintained at $37^{\circ} \mathrm{C}$ in a humidified $5 \% \mathrm{CO}_{2} / 95 \%$ air atmosphere.

HEK293 cells were transiently transfected with Effectene ${ }^{\circledR}$ Transfection Reagent (Qiagen), using $400 \mathrm{ng}$ of a plasmid encoding the hTRPM2 channel, and $50 \mathrm{ng}$ of a plasmid encoding CD8 [92]. Beads covered with anti-CD8 antibodies were used to identify positively transfected cells, as described in [92]. Currents were recorded 24-48 h after transfection.

\subsection{Chemicals}

All chemicals were purchased from Sigma. Stock solutions of paxilline, N-(p-amy lcinnamoyl)anthranilic acid (ACA), bis(4-fluorophenyl)phenyl acetamide (senicapoc), and 1-(o-chloro- $\alpha, \alpha$-diphenylbenzyl)imidazole (clotrimazole) were prepared in DMSO and dissolved in the working solution immediately prior to the experiments. DMSO never exceeded $0.1 \%$. Luperox ${ }^{\circledR}$ TBH70X tert-Butyl hydroperoxide (TBH70X) solution, was dissolved in external working solution immediately prior to the experiments.

\subsection{Patch-Clamp Experiments}

For whole-cell patch-clamp experiments, the standard pipette (intracellular) solution contained (in mM): $8 \mathrm{NaCl}, 100 \mathrm{~K}$-Aspartate, $40 \mathrm{KCl}, 10 \mathrm{EGTA}, 10 \mathrm{HEPES}$, and $2 \mathrm{CaCl}_{2}$ ( $\mathrm{pH}$ 7.3). The free $\mathrm{Ca}^{2+}$ concentration in this solution was $\sim 20 \mathrm{nM}$. The composition of the used extracellular solutions is indicated in Table 1.

Seal resistance was $>1 \mathrm{G} \Omega$. The standard current-voltage protocol for stimulation consisted of 500-ms-long voltage steps from -80 to $120 \mathrm{mV}$, in $20 \mathrm{mV}$ increments, starting from a holding potential of $-50 \mathrm{mV}$. The response of patch-clamped cells to the various stimuli was monitored using the "time-course protocol", which consisted of a "staircase" of 50 -ms pulses to $-100,-50,0,50$, and $100 \mathrm{mV}$, administered every $5 \mathrm{~s}$. No leak-current subtraction was performed. Membrane currents were filtered at $5 \mathrm{kHz}$ and digitized at $20 \mathrm{kHz}$ with a National Instruments DAQ interface employing the GePulse acquisition program (freely available at http:/ / users.ge.ibf.cnr.it/pusch/programs-mik.htm), as described in [93-95]. Raw data were analyzed using the freely available Ana analysis program (http:/ /users.ge.ibf.cnr.it/pusch/programs-mik.htm). Figures were prepared using SigmaPlot (Systat Software Inc. (SSI), San Jose, CA, USA).

\section{4. $\mathrm{Ca}^{2+}$ Imaging with Fura-2-AM}

Measurements of intracellular $\mathrm{Ca}^{2+}\left(\left[\mathrm{Ca}^{2+}\right]_{\mathrm{i}}\right)$ were performed using the fluorescent $\mathrm{Ca}^{2+}$ indicator fura-2 AM. Cells were loaded with $5 \mu \mathrm{M}$ of fura-2 AM dissolved in extracellular solution with $0.1 \%$ pluronic acid to improve dye uptake, for $45 \mathrm{~min}$ at $37^{\circ} \mathrm{C}$. Cell coverslips were placed on the stage of an inverted Nikon TE200 fluorescence microscope (Nikon, Tokyo, Japan) equipped with a dual-excitation fluorometric $\mathrm{Ca}^{2+}$ imaging system (Hamamatsu, 325-6, Sunayama-cho, Naka-ku, Hamamatsu City, Shizuoka, Japan). Cells were excited at 340 and $380 \mathrm{~nm}$, at a sampling rate of $0.5 \mathrm{~Hz}$, and fluorescence emission, measured at $510 \mathrm{~nm}$, was acquired with a digital CCD camera (Hamamatsu C4742-9512ER). The external solutions were the same as used in the patch-clamp experiments. The fluorescence ratio F340/F380 was used to monitor $\left[\mathrm{Ca}^{2+}\right]_{\mathrm{i}}$ changes. Monochromator settings, chopper frequency, and data acquisition were controlled with dedicated software (Aquacosmos/Ratio U7501-01, Hamamatsu, Japan). $\left[\mathrm{Ca}^{2+}\right]_{\mathrm{i}}$ was calculated according to the method of Grynkiewicz et al. [96], using a KD of $140 \mathrm{nM}$ for the $\mathrm{Ca}^{2+} /$ fura-2 complex. Data were analyzed using SigmaPlot 8.0 software. Results are presented as mean \pm standard error of different cells from at least 4 independent experiments. 


\subsection{Real-Time $q P C R$}

Total RNA was extracted from IGR39 or IGR37 cells grown to subconfluency in a $25-\mathrm{cm}^{2}$ flask, using the Aurum Total RNA Mini Kit (Bio-Rad, Hercules, CA, USA) according to the manufacturer's instructions. RNA was quantified by measuring the absorbance with a spectrophotometer, and $1 \mu \mathrm{g}$ was reverse-transcribed using the IScript advanced cDNA synthesis kit (Bio-Rad), including both oligo (dT) and random primers and the RNAse $\mathrm{H}+\mathrm{MMLV}$ reverse transcriptase enzyme. Alternatively, RNA was extracted with the PureLink RNA mini kit (Ambion) and $1 \mu \mathrm{g}$ was reverse-transcribed using the SuperScript IV VILO cDNA synthesis kit (Thermo Fisher Scientific). The cDNAs obtained were used as templates for real-time PCR. Gene expression was generally assessed via SYBR Green quantitative real-time PCR using the SsoAdvanced Universal SYBR Green Supermix in the Bio-Rad CFX Connect Instrument. The thermal protocol consisted of a denaturation step at $95^{\circ} \mathrm{C}$ for $3 \mathrm{~min}$, followed by 39 two-step cycles composed of a denaturation step at $95^{\circ} \mathrm{C}$ for $10 \mathrm{~s}$ and annealing/extension at $55^{\circ} \mathrm{C}$ for $30 \mathrm{~s}$. Amplification was performed using the oligonucleotide primers listed in Table S1. Primer design was performed with ProbeFinder (qpcr.probefinder.com, Roche) and checked for specificity with ensembl.org. When possible, primers were designed to span 2 exons, and amplicon length never exceeded $150 \mathrm{bp}$. The expression of each target gene was assessed in triplicate and normalized to the expression of the housekeeping gene actin. To avoid false positives, several controls-i.e., no template control (NTC), no primer control (NPC), and no reverse transcription control (NAC)-were included. At the end of amplification, a melting curve was run to check the specificity of the polymerization, and to visualize the presence of primer dimers or spurious products.

For the KCNMA1 and KCNK2 genes the expression was also verified with TAQMAN probes, using GAPDH as a reference housekeeping gene (Applied Biosystems Assay IDs: Hs02758991-g1 for GAPDH; Hs01119504_m1 for KCNMA1; Hs 01005159-m1 for KCNK2). The thermal protocol optimized for TaqMan gene expression consisted of an enzyme activation step at $95^{\circ} \mathrm{C}$ for $2 \mathrm{~min}$, followed by 39 two-step cycles, composed of denaturation for $3 \mathrm{~s}$ at $95^{\circ} \mathrm{C}$, and annealing/extension for $30 \mathrm{~s}$ at $60^{\circ} \mathrm{C}$. Results were visualized with Bio-Rad's CFX manager software, while subsequent data analysis was performed using SigmaPlot (SPSS Inc., Chicago, IL, USA).

\subsection{In Silico Gene Expression Analysis}

The following GEO datasets were used for in silico analysis: GSE137391, GSE88741, GSE35704, and GSE107620. Expression data for each cell line and gene were normalized to the respective expression of the ribosomal RPL19 gene. For Figure 4b, raw data from the GSE137391 dataset were aligned to the human genome. Sequences were trimmed using Trimgalore, and those that aligned to human rRNAs using Bowtie (v. 1.2.2 [97]) were discarded. Unmapped sequences were aligned to the human genome (GRCh38 Primary Assembly) using STAR (v.STAR-2.7.1a [98]) with Ensembl gene annotation (release 99). SAMtools (v. 1.8) was used to mark duplicated sequences, and StringTie (v. 1.3.6) was used to estimate gene abundances. EdgeR [99] was used for differential expression analysis, filtering genes with low expression ( $<5$ counts). In Figure $8 \mathbf{b}$, expression values for KCNMA1, KCNN4, TRPM2, and TRPM1 are shown for the melanocyte and melanoma cell lines of these datasets.

\subsection{Statistics}

Data are shown as representative experiments or as mean \pm SEM. The statistical significance of differences between groups of data was assessed using Student's $t$-test.

Supplementary Materials: The following are available online at https://www.mdpi.com/article/10 $.3390 /$ ijms22168359/s1. 
Author Contributions: Conceptualization, L.F., P.G. and M.P.; data curation, M.R.F.; funding acquisition, C.A.M.L.P., P.G. and M.P.; investigation, L.F., R.B., C.P., P.Z., A.R., S.B., G.Z., P.G. and M.P.; visualization, M.P.; writing-original draft, L.F., P.G. and M.P.; writing-review and editing, L.F., R.B., C.P., P.Z., A.R., S.B., G.Z., C.A.M.L.P., P.G. and M.P. All authors have read and agreed to the published version of the manuscript.

Funding: This work was supported by a grant from the Fondazione AIRC per la Ricerca sul Cancro (grant \# IG 21558) and the Italian Research Ministry (PRIN 20174TB8KW) to M. Pusch.

Institutional Review Board Statement: The study did not involve humans or animals.

Data Availability Statement: Original data are available from the authors on request.

Acknowledgments: We thank Francesca Quartino for expert technical assistance. We thank Dawon Kang (Gyeongsang National University, Chinju, South Korea) for hTREK1 and hTREK2 plasmids, Pablo Cid (Centro de Estudios Cientificos, Valdivia, Chile) for hTALK2 and mTASK2 plasmids, and Martin Stocker (Research Department of Neuroscience, Physiology, and Pharmacology, University College London, Gower St., London, UK).

Conflicts of Interest: The authors declare no conflict of interest.

\section{References}

1. Hille, B. Ion Channels of Excitable Membranes, 3rd ed.; Sinauer: Sunderland, UK, 2001.

2. Zheng, J.; Trudeau, M.C. Handbook of Ion Channels; CRC Press: Boca Raton, FL, USA, 2016; p. 691.

3. Marino, A.; Dossena, S.; Tamma, G.; Donnini, S. Oxidative stress and membrane transport systems. Oxid. Med. Cell Longev. 2018, 2018, 9625213. [CrossRef]

4. Singh, A.; Kukreti, R.; Saso, L.; Kukreti, S. Oxidative stress: A key modulator in neurodegenerative diseases. Molecules 2019, 24, 1583. [CrossRef]

5. Xu, T.; Ding, W.; Ji, X.; Ao, X.; Liu, Y.; Yu, W.; Wang, J. Oxidative stress in cell death and cardiovascular diseases. Oxid. Med. Cell Longev. 2019, 2019, 9030563. [CrossRef] [PubMed]

6. Rehman, K.; Akash, M.S.H. Mechanism of generation of oxidative stress and pathophysiology of type 2 diabetes mellitus: How are they interlinked? J. Cell. Biochem. 2017, 118, 3577-3585. [CrossRef] [PubMed]

7. Davalli, P.; Mitic, T.; Caporali, A.; Lauriola, A.; D'Arca, D. ROS, Cell Senescence, and Novel Molecular Mechanisms in Aging and Age-Related Diseases. Oxid. Med. Cell. Longev. 2016, 2016, 3565127. [CrossRef] [PubMed]

8. Gorrini, C.; Harris, I.S.; Mak, T.W. Modulation of oxidative stress as an anticancer strategy. Nat. Rev. Drug Discov. 2013, 12, 931-947. [CrossRef]

9. Gupta, R.K.; Patel, A.K.; Shah, N.; Chaudhary, A.K.; Jha, U.K.; Yadav, U.C.; Gupta, P.K.; Pakuwal, U. Oxidative stress and antioxidants in disease and cancer: A review. Asian Pac. J. Cancer Prev. 2014, 15, 4405-4409. [CrossRef] [PubMed]

10. Sosa, V.; Moline, T.; Somoza, R.; Paciucci, R.; Kondoh, H.; ME, L.L. Oxidative stress and cancer: An overview. Ageing Res. Rev. 2013, 12, 376-390. [CrossRef]

11. Sies, H. Oxidative stress: A concept in redox biology and medicine. Redox Biol. 2015, 4, 180-183. [CrossRef] [PubMed]

12. Remigante, A.; Morabito, R.; Marino, A. Band 3 protein function and oxidative stress in erythrocytes. J. Cell Physiol. 2021, 236, 6225-6234. [CrossRef]

13. Remigante, A.; Morabito, R.; Marino, A. Natural Antioxidants Beneficial Effects on Anion Exchange through Band 3 Protein in Human Erythrocytes. Antioxidants 2019, 9, 25. [CrossRef]

14. Zuniga-Garcia, V.; Chavez-Lopez Mde, G.; Quintanar-Jurado, V.; Gabino-Lopez, N.B.; Hernandez-Gallegos, E.; Soriano-Rosas, J.; Perez-Carreon, J.I.; Camacho, J. Differential Expression of Ion Channels and Transporters During Hepatocellular Carcinoma Development. Dig. Dis. Sci. 2015, 60, 2373-2383. [CrossRef]

15. Vogt, W. Oxidation of methionyl residues in proteins: Tools, targets, and reversal. Free Radic. Biol. Med. 1995, 18, 93-105. [CrossRef]

16. Santarelli, L.C.; Wassef, R.; Heinemann, S.H.; Hoshi, T. Three methionine residues located within the regulator of conductance for $\mathrm{K}^{+}$(RCK) domains confer oxidative sensitivity to large-conductance Ca2 ${ }^{+}$-activated $\mathrm{K}^{+}$channels. J. Physiol. 2006, 571, 329-348. [CrossRef] [PubMed]

17. Fricke, T.C.; Echtermeyer, F.; Zielke, J.; de la Roche, J.; Filipovic, M.R.; Claverol, S.; Herzog, C.; Tominaga, M.; Pumroy, R.A.; Moiseenkova-Bell, V.Y.; et al. Oxidation of methionine residues activates the high-threshold heat-sensitive ion channel TRPV2. Proc. Natl. Acad. Sci. USA 2019, 116, 24359-24365. [CrossRef] [PubMed]

18. Anderson, K.J.; Cormier, R.T.; Scott, P.M. Role of ion channels in gastrointestinal cancer. World J. Gastroenterol. 2019, 25, 5732-5772. [CrossRef]

19. Ahmad, S.; Khan, M.Y.; Rafi, Z.; Khan, H.; Siddiqui, Z.; Rehman, S.; Shahab, U.; Khan, M.S.; Saeed, M.; Alouffi, S. Oxidation, glycation and glycoxidation-The vicious cycle and lung cancer. Semin. Cancer Biol. 2018, 49, 29-36. [CrossRef] 
20. Venza, M.; Visalli, M.; Beninati, C.; De Gaetano, G.V.; Teti, D.; Venza, I. Cellular Mechanisms of Oxidative Stress and Action in Melanoma. Oxid. Med. Cell. Longev. 2015, 2015, 481782. [CrossRef]

21. Pardo, L.A.; Stühmer, W. The roles of K(+) channels in cancer. Nat. Rev. Cancer 2014, 14, 39-48. [CrossRef]

22. Böhme, I.; Schönherr, R.; Eberle, J.; Bosserhoff, A.K. Membrane transporters and channels in melanoma. Rev. Physiol. Biochem. Pharmacol. 2020. [CrossRef]

23. Yde, S.S.; Sjoegren, P.; Heje, M.; Stolle, L.B. Mucosal Melanoma: A Literature Review. Curr. Oncol. Rep. 2018, 20, 28. [CrossRef] [PubMed]

24. Abbas, O.; Miller, D.D.; Bhawan, J. Cutaneous malignant melanoma: Update on diagnostic and prognostic biomarkers. Am. J. Dermatopathol. 2014, 36, 363-379. [CrossRef] [PubMed]

25. Rosa, P.; Catacuzzeno, L.; Sforna, L.; Mangino, G.; Carlomagno, S.; Mincione, G.; Petrozza, V.; Ragona, G.; Franciolini, F.; Calogero, A. BK channels blockage inhibits hypoxia-induced migration and chemoresistance to cisplatin in human glioblastoma cells. $J$. Cell. Physiol. 2018, 233, 6866-6877. [CrossRef]

26. Sizemore, G.; McLaughlin, S.; Newman, M.; Brundage, K.; Ammer, A.; Martin, K.; Pugacheva, E.; Coad, J.; Mattes, M.D.; Yu, H.G. Opening large-conductance potassium channels selectively induced cell death of triple-negative breast cancer. BMC Cancer 2020, 20, 595. [CrossRef] [PubMed]

27. Goda, A.A.; Siddique, A.B.; Mohyeldin, M.; Ayoub, N.M.; El Sayed, K.A. The Maxi-K (BK) Channel Antagonist Penitrem A as a Novel Breast Cancer-Targeted Therapeutic. Mar. Drugs 2018, 16, 0157. [CrossRef]

28. Tajima, N.; Itokazu, Y.; Korpi, E.R.; Somerharju, P.; Kakela, R. Activity of BK(Ca) channel is modulated by membrane cholesterol content and association with $\mathrm{Na}+$ /K+-ATPase in human melanoma IGR39 cells. J. Biol. Chem. 2011, 286, 5624-5638. [CrossRef] [PubMed]

29. Cambien, B.; Rezzonico, R.; Vitale, S.; Rouzaire-Dubois, B.; Dubois, J.M.; Barthel, R.; Soilihi, B.K.; Mograbi, B.; Schmid-Alliana, A.; Schmid-Antomarchi, H. Silencing of hSlo potassium channels in human osteosarcoma cells promotes tumorigenesis. Int. J. Cancer 2008, 123, 365-371. [CrossRef]

30. Latorre, R.; Castillo, K.; Carrasquel-Ursulaez, W.; Sepulveda, R.V.; Gonzalez-Nilo, F.; Gonzalez, C.; Alvarez, O. Molecular Determinants of BK Channel Functional Diversity and Functioning. Physiol. Rev. 2017, 97, 39-87. [CrossRef] [PubMed]

31. Feng, B.; Ye, W.L.; Ma, L.J.; Fang, Y.; Mei, Y.A.; Wei, S.M. Hydrogen peroxide enhanced Ca $\left(2^{+}\right)$-activated BK currents and promoted cell injury in human dermal fibroblasts. Life Sci. 2012, 90, 424-431. [CrossRef] [PubMed]

32. Liu, B.; Sun, X.; Zhu, Y.; Gan, L.; Xu, H.; Yang, X. Biphasic effects of $\mathrm{H}(2) \mathrm{O}(2)$ on $\mathrm{BK}(\mathrm{Ca})$ channels. Free Radic. Res. 2010, 44, 1004-1012. [CrossRef] [PubMed]

33. Hermann, A.; Sitdikova, G.F.; Weiger, T.M. Oxidative Stress and Maxi Calcium-Activated Potassium (BK) Channels. Biomolecules 2015, 5, 1870-1911. [CrossRef] [PubMed]

34. Klumpp, L.; Sezgin, E.C.; Skardelly, M.; Eckert, F.; Huber, S.M. KCa3.1 Channels and Glioblastoma: In Vitro Studies. Curr. Neuropharmacol. 2018, 16, 627-635. [CrossRef]

35. De Marchi, U.; Sassi, N.; Fioretti, B.; Catacuzzeno, L.; Cereghetti, G.M.; Szabo, I.; Zoratti, M. Intermediate conductance Ca2+ activated potassium channel (KCa3.1) in the inner mitochondrial membrane of human colon cancer cells. Cell Calcium 2009, 45, 509-516. [CrossRef] [PubMed]

36. Sassi, N.; De Marchi, U.; Fioretti, B.; Biasutto, L.; Gulbins, E.; Franciolini, F.; Szabo, I.; Zoratti, M. An investigation of the occurrence and properties of the mitochondrial intermediate-conductance $\mathrm{Ca}^{+}$-activated $\mathrm{K}^{+}$channel mtKCa3.1. Biochim. Biophys. Acta 2010, 1797, 1260-1267. [CrossRef] [PubMed]

37. Kovalenko, I.; Glasauer, A.; Schockel, L.; Sauter, D.R.; Ehrmann, A.; Sohler, F.; Hagebarth, A.; Novak, I.; Christian, S. Identification of KCa3.1 channel as a novel regulator of oxidative phosphorylation in a subset of pancreatic carcinoma cell lines. PLoS ONE 2016, 11, e0160658. [CrossRef]

38. Tajada, S.; Villalobos, C. Calcium permeable channels in cancer hallmarks. Front. Pharmacol. 2020, 11, 968. [CrossRef]

39. Girault, A.; Ahidouch, A.; Ouadid-Ahidouch, H. Roles for $\mathrm{Ca}\left(2^{+}\right)$and $\left.\mathrm{K}^{+}\right)$channels in cancer cells exposed to the hypoxic tumour microenvironment. Biochim. Biophys. Acta Mol. Cell. Res. 2020, 1867, 118644. [CrossRef]

40. Moloney, J.N.; Cotter, T.G. ROS signalling in the biology of cancer. Semin. Cell Dev. Biol. 2018, 80, 50-64. [CrossRef]

41. Stueber, T.; Eberhardt, M.J.; Caspi, Y.; Lev, S.; Binshtok, A.; Leffler, A. Differential cytotoxicity and intracellular calcium-signalling following activation of the calcium-permeable ion channels TRPV1 and TRPA1. Cell Calcium 2017, 68, 34-44. [CrossRef]

42. Kraft, R.; Grimm, C.; Grosse, K.; Hoffmann, A.; Sauerbruch, S.; Kettenmann, H.; Schultz, G.; Harteneck, C. Hydrogen peroxide and ADP-ribose induce TRPM2-mediated calcium influx and cation currents in microglia. Am. J. Physiol. Cell Physiol. 2004, 286, C129-C137. [CrossRef]

43. Miller, B.A. TRPM2 in cancer. Cell Calcium 2019, 80, 8-17. [CrossRef]

44. Ji, D.; Luo, Z.W.; Ovcjak, A.; Alanazi, R.; Bao, M.H.; Feng, Z.P.; Sun, H.S. Role of TRPM2 in brain tumours and potential as a drug target. Acta Pharmacol. Sin. 2021, 1-12. [CrossRef]

45. Gokce Kutuk, S.; Gokce, G.; Kutuk, M.; Gurses Cila, H.E.; Naziroglu, M. Curcumin enhances cisplatin-induced human laryngeal squamous cancer cell death through activation of TRPM2 channel and mitochondrial oxidative stress. Sci. Rep. 2019, 9, 17784. [CrossRef] [PubMed]

46. Wang, Q.; Huang, L.; Yue, J. Oxidative stress activates the TRPM2-Ca(2+)-CaMKII-ROS signaling loop to induce cell death in cancer cells. Biochim. Biophys. Acta. Mol. Cell Res. 2017, 1864, 957-967. [CrossRef] 
47. Miller, B.A.; Wang, J.; Song, J.; Zhang, X.Q.; Hirschler-Laszkiewicz, I.; Shanmughapriya, S.; Tomar, D.; Rajan, S.; Feldman, A.M.; Madesh, M.; et al. Trpm2 enhances physiological bioenergetics and protects against pathological oxidative cardiac injury: Role of Pyk2 phosphorylation. J. Cell Physiol. 2019. [CrossRef] [PubMed]

48. Miller, B.A.; Cheung, J.Y. TRPM2 protects against tissue damage following oxidative stress and ischaemia-reperfusion. J. Physiol. 2016, 594, 4181-4191. [CrossRef] [PubMed]

49. Ge, L.; Hoa, N.T.; Wilson, Z.; Arismendi-Morillo, G.; Kong, X.T.; Tajhya, R.B.; Beeton, C.; Jadus, M.R. Big Potassium (BK) ion channels in biology, disease and possible targets for cancer immunotherapy. Int. Immunopharmacol. 2014, 22, 427-443. [CrossRef] [PubMed]

50. Bentzen, B.H.; Olesen, S.P.; Ronn, L.C.; Grunnet, M. BK channel activators and their therapeutic perspectives. Front. Physiol. 2014, 5, 389. [CrossRef]

51. Xia, J.; Wang, H.; Li, S.; Wu, Q.; Sun, L.; Huang, H.; Zeng, M. Ion channels or aquaporins as novel molecular targets in gastric cancer. Mol. Cancer 2017, 16, 54. [CrossRef]

52. Sterea, A.M.; Egom, E.E.; El Hiani, Y. TRP channels in gastric cancer: New hopes and clinical perspectives. Cell Calcium 2019, 82, 102053. [CrossRef]

53. Meyer, R.; Schönherr, R.; Gavrilova-Ruch, O.; Wohlrab, W.; Heinemann, S.H. Identification of ether a go-go and calcium-activated potassium channels in human melanoma cells. J. Membr. Biol. 1999, 171, 107-115. [CrossRef] [PubMed]

54. Tajima, N.; Schonherr, K.; Niedling, S.; Kaatz, M.; Kanno, H.; Schonherr, R.; Heinemann, S.H. Ca ${ }^{2+}$-activated ${ }^{+}$channels in human melanoma cells are up-regulated by hypoxia involving hypoxia-inducible factor-1alpha and the von Hippel-Lindau protein. J. Physiol. 2006, 571, 349-359. [CrossRef] [PubMed]

55. Langton, P.D.; Nelson, M.T.; Huang, Y.; Standen, N.B. Block of calcium-activated potassium channels in mammalian arterial myocytes by tetraethylammonium ions. Am. J. Physiol. 1991, 260, H927-H934. [CrossRef]

56. Zhou, Y.; Lingle, C.J. Paxilline inhibits BK channels by an almost exclusively closed-channel block mechanism. J. Gen. Physiol. 2014, 144, 415-440. [CrossRef] [PubMed]

57. Duprat, F.; Girard, C.; Jarretou, G.; Lazdunski, M. Pancreatic two P domain $\mathrm{K}^{+}$channels TALK-1 and TALK-2 are activated by nitric oxide and reactive oxygen species. J. Physiol. 2005, 562, 235-244. [CrossRef] [PubMed]

58. Tarasov, M.V.; Kotova, P.D.; Bystrova, M.F.; Kabanova, N.V.; Sysoeva, V.Y.; Kolesnikov, S.S. Arachidonic acid hyperpolarizes mesenchymal stromal cells from the human adipose tissue by stimulating TREK1 $\mathrm{K}\left({ }^{+}\right)$channels. Channels 2019, $13,36-47$. [CrossRef]

59. Papreck, J.R.; Martin, E.A.; Lazzarini, P.; Kang, D.; Kim, D. Modulation of K2P3.1 (TASK-1), K2P9.1 (TASK-3), and TASK-1/3 heteromer by reactive oxygen species. Pflugers Arch. 2012, 464, 471-480. [CrossRef]

60. Wei, A.D.; Gutman, G.A.; Aldrich, R.; Chandy, K.G.; Grissmer, S.; Wulff, H. International Union of Pharmacology. LII. Nomenclature and molecular relationships of calcium-activated potassium channels. Pharmacol. Rev. 2005, 57, 463-472. [CrossRef]

61. McNaughton-Smith, G.A.; Burns, J.F.; Stocker, J.W.; Rigdon, G.C.; Creech, C.; Arrington, S.; Shelton, T.; de Franceschi, L. Novel inhibitors of the Gardos channel for the treatment of sickle cell disease. J. Med. Chem. 2008, 51, 976-982. [CrossRef]

62. Nguyen, H.M.; Singh, V.; Pressly, B.; Jenkins, D.P.; Wulff, H.; Yarov-Yarovoy, V. Structural Insights into the Atomistic Mechanisms of Action of Small Molecule Inhibitors Targeting the KCa3.1 Channel Pore. Mol. Pharmacol. 2017, 91, 392-402. [CrossRef]

63. Ataga, K.I.; Smith, W.R.; De Castro, L.M.; Swerdlow, P.; Saunthararajah, Y.; Castro, O.; Vichinsky, E.; Kutlar, A.; Orringer, E.P.; Rigdon, G.C.; et al. Efficacy and safety of the Gardos channel blocker, senicapoc (ICA-17043), in patients with sickle cell anemia. Blood 2008, 111, 3991-3997. [CrossRef]

64. Bessac, B.F.; Sivula, M.; von Hehn, C.A.; Escalera, J.; Cohn, L.; Jordt, S.E. TRPA1 is a major oxidant sensor in murine airway sensory neurons. J. Clin. Investig. 2008, 118, 1899-1910. [CrossRef] [PubMed]

65. Hack, C.T.; Buck, T.; Bagnjuk, K.; Eubler, K.; Kunz, L.; Mayr, D.; Mayerhofer, A. A Role for H2O2 and TRPM2 in the Induction of Cell Death: Studies in KGN Cells. Antioxidants 2019, 8, 518. [CrossRef] [PubMed]

66. Hill, K.; McNulty, S.; Randall, A.D. Inhibition of TRPM2 channels by the antifungal agents clotrimazole and econazole. Naunyn Schmiedebergs Arch. Pharmacol. 2004, 370, 227-237. [CrossRef]

67. Kraft, R.; Grimm, C.; Frenzel, H.; Harteneck, C. Inhibition of TRPM2 cation channels by N-(p-amylcinnamoyl)anthranilic acid. Br. J. Pharmacol. 2006, 148, 264-273. [CrossRef] [PubMed]

68. Ito, C.; Tecchio, C.; Coustan-Smith, E.; Suzuki, T.; Behm, F.G.; Raimondi, S.C.; Pui, C.H.; Campana, D. The antifungal antibiotic clotrimazole alters calcium homeostasis of leukemic lymphoblasts and induces apoptosis. Leukemia 2002, 16, 1344-1352. [CrossRef] [PubMed]

69. D'Arcangelo, D.; Scatozza, F.; Giampietri, C.; Marchetti, P.; Facchiano, F.; Facchiano, A. Ion Channel Expression in Human Melanoma Samples: In Silico Identification and Experimental Validation of Molecular Targets. Cancers 2019, 11, 446. [CrossRef]

70. Salinas, M.; Reyes, R.; Lesage, F.; Fosset, M.; Heurteaux, C.; Romey, G.; Lazdunski, M. Cloning of a new mouse two-P domain channel subunit and a human homologue with a unique pore structure. J. Biol Chem. 1999, 274, 11751-11760. [CrossRef]

71. Daenen, K.; Andries, A.; Mekahli, D.; Van Schepdael, A.; Jouret, F.; Bammens, B. Oxidative stress in chronic kidney disease. Pediatr. Nephrol. 2019, 34, 975-991. [CrossRef] [PubMed]

72. Eisfeld, J.; Luckhoff, A. Trpm2. Handbook of Experimental Pharmacology; Springer: Berlin/Heidelberg, Germany, 2007; pp. 237-252. [CrossRef] 
73. Meseguer, V.; Karashima, Y.; Talavera, K.; D’Hoedt, D.; Donovan-Rodriguez, T.; Viana, F.; Nilius, B.; Voets, T. Transient receptor potential channels in sensory neurons are targets of the antimycotic agent clotrimazole. J. Neurosci. 2008, 28, 576-586. [CrossRef] [PubMed]

74. Harteneck, C.; Frenzel, H.; Kraft, R. N-(p-amylcinnamoyl)anthranilic acid (ACA): A phospholipase A(2) inhibitor and TRP channel blocker. Cardiovasc. Drug Rev. 2007, 25, 61-75. [CrossRef] [PubMed]

75. Zhang, H.; Zhao, S.; Yu, J.; Yang, W.; Liu, Z.; Zhang, L. Medicinal chemistry perspective of TRPM2 channel inhibitors: Where we are and where we might be heading? Drug Discov. Today 2020, 25, 2326-2334. [CrossRef] [PubMed]

76. Jiang, H.; Zeng, B.; Chen, G.L.; Bot, D.; Eastmond, S.; Elsenussi, S.E.; Atkin, S.L.; Boa, A.N.; Xu, S.Z. Effect of non-steroidal anti-inflammatory drugs and new fenamate analogues on TRPC4 and TRPC5 channels. Biochem. Pharmacol. 2012, 83, 923-931. [CrossRef]

77. Kashio, M.; Sokabe, T.; Shintaku, K.; Uematsu, T.; Fukuta, N.; Kobayashi, N.; Mori, Y.; Tominaga, M. Redox signal-mediated sensitization of transient receptor potential melastatin 2 (TRPM2) to temperature affects macrophage functions. Proc. Natl. Acad. Sci. USA 2012, 109, 6745-6750. [CrossRef]

78. Huang, C.; Gan, D.; Fan, C.; Wen, C.; Li, A.; Li, Q.; Zhao, J.; Wang, Z.; Zhu, L.; Lu, D. The Secretion from Neural Stem Cells Pretreated with Lycopene Protects against tert-Butyl Hydroperoxide-Induced Neuron Oxidative Damage. Oxid. Med. Cell Longev. 2018, 2018, 5490218. [CrossRef] [PubMed]

79. Gradogna, A.; Gavazzo, P.; Boccaccio, A.; Pusch, M. Subunit-dependent oxidative stress sensitivity of LRRC8 volume-regulated anion channels. J. Physiol. 2017, 595, 6719-6733. [CrossRef]

80. Tang, X.D.; Daggett, H.; Hanner, M.; Garcia, M.L.; McManus, O.B.; Brot, N.; Weissbach, H.; Heinemann, S.H.; Hoshi, T. Oxidative regulation of large conductance calcium-activated potassium channels. J. Gen. Physiol. 2001, 117, 253-274. [CrossRef]

81. Mazar, J.; DeYoung, K.; Khaitan, D.; Meister, E.; Almodovar, A.; Goydos, J.; Ray, A.; Perera, R.J. The regulation of miRNA-211 expression and its role in melanoma cell invasiveness. PLoS ONE 2010, 5, e13779. [CrossRef]

82. Agaimy, A.; Specht, K.; Stoehr, R.; Lorey, T.; Markl, B.; Niedobitek, G.; Straub, M.; Hager, T.; Reis, A.C.; Schilling, B.; et al. Metastatic Malignant Melanoma with Complete Loss of Differentiation Markers (Undifferentiated/Dedifferentiated Melanoma): Analysis of 14 Patients Emphasizing Phenotypic Plasticity and the Value of Molecular Testing as Surrogate Diagnostic Marker. Am. J. Surg. Pathol. 2016, 40, 181-191. [CrossRef]

83. Lin, R.; Wang, Y.; Chen, Q.; Liu, Z.; Xiao, S.; Wang, B.; Shi, B. TRPM2 promotes the proliferation and invasion of pancreatic ductal adenocarcinoma. Mol. Med. Rep. 2018, 17, 7537-7544. [CrossRef]

84. Du, C.; Zheng, Z.; Li, D.; Chen, L.; Li, N.; Yi, X.; Yang, Y.; Guo, F.; Liu, W.; Xie, X.; et al. BKCa promotes growth and metastasis of prostate cancer through facilitating the coupling between alphavbeta3 integrin and FAK. Oncotarget 2016, 7, 40174-40188. [CrossRef]

85. Hoa, N.T.; Ge, L.; Tajhya, R.B.; Beeton, C.; Cornforth, A.N.; Abolhoda, A.; Lambrecht, N.; DaCosta-Iyer, M.; Ouyang, Y.; Mai, A.P.; et al. Small cell lung cancer cells express the late stage gBK tumor antigen: A possible immunotarget for the terminal disease. Am. J. Transl. Res. 2014, 6, 188-205.

86. Ma, Y.G.; Liu, W.C.; Dong, S.; Du, C.; Wang, X.J.; Li, J.S.; Xie, X.P.; Wu, L.; Ma, D.C.; Yu, Z.B.; et al. Activation of BK(Ca) channels in zoledronic acid-induced apoptosis of MDA-MB-231 breast cancer cells. PLoS ONE 2012, 7, e37451. [CrossRef]

87. Mohr, C.J.; Schroth, W.; Murdter, T.E.; Gross, D.; Maier, S.; Stegen, B.; Dragoi, A.; Steudel, F.A.; Stehling, S.; Hoppe, R.; et al Subunits of BK channels promote breast cancer development and modulate responses to endocrine treatment in preclinical models. Br. J. Pharmacol. 2020. [CrossRef] [PubMed]

88. Khaitan, D.; Sankpal, U.T.; Weksler, B.; Meister, E.A.; Romero, I.A.; Couraud, P.O.; Ningaraj, N.S. Role of KCNMA1 gene in breast cancer invasion and metastasis to brain. BMC Cancer 2009, 9, 258. [CrossRef] [PubMed]

89. Schmidt, J.; Friebel, K.; Schönherr, R.; Coppolino, M.G.; Bosserhoff, A.K. Migration-associated secretion of melanoma inhibitory activity at the cell rear is supported by KCa3.1 potassium channels. Cell Res. 2010, 20, 1224-1238. [CrossRef] [PubMed]

90. Brown, B.M.; Pressley, B.; Wulff, H. KCa3.1 Channel Modulators as Potential Therapeutic Compounds for Glioblastoma. Curr. Neuropharmacol. 2018, 16, 618-626. [CrossRef] [PubMed]

91. Catacuzzeno, L.; Sforna, L.; Esposito, V.; Limatola, C.; Franciolini, F. Ion Channels in Glioma Malignancy. Rev. Physiol. Biochem. Pharmacol. 2020. [CrossRef]

92. Jurman, M.E.; Boland, L.M.; Liu, Y.; Yellen, G. Visual identification of individual transfected cells for electrophysiology using antibody-coated beads. Biotechniques 1994, 17, 876-881.

93. Pusch, M.; Zifarelli, G. Large transient capacitive currents in wild-type lysosomal $\mathrm{Cl}^{-} / \mathrm{H}^{+}$antiporter $\mathrm{ClC}-7$ and residual transport activity in the proton glutamate mutant E312A. J. Gen. Physiol. 2021, 153. [CrossRef] [PubMed]

94. Bertelli, S.; Barbieri, R.; Pusch, M.; Gavazzo, P. Gain of function of sporadic/familial hemiplegic migraine-causing SCN1A mutations: Use of an optimized cDNA. Cephalalgia Int. J. Headache 2018, 39, 477-488. [CrossRef] [PubMed]

95. Barbieri, R.; Bertelli, S.; Pusch, M.; Gavazzo, P. Late sodium current blocker GS967 inhibits persistent currents induced by familial hemiplegic migraine type 3 mutations of the SCN1A gene. J. Headache Pain 2019, 20, 107. [CrossRef]

96. Grynkiewicz, G.; Poenie, M.; Tsien, R.Y. A new generation of Ca2+ indicators with greatly improved fluorescence properties. J. Biol. Chem. 1985, 260, 3440-3450. [CrossRef]

97. Langmead, B.; Trapnell, C.; Pop, M.; Salzberg, S.L. Ultrafast and memory-efficient alignment of short DNA sequences to the human genome. Genome Biol. 2009, 10, R25. [CrossRef] [PubMed] 
98. Dobin, A.; Davis, C.A.; Schlesinger, F.; Drenkow, J.; Zaleski, C.; Jha, S.; Batut, P.; Chaisson, M.; Gingeras, T.R. STAR: Ultrafast universal RNA-seq aligner. Bioinformatics 2013, 29, 15-21. [CrossRef]

99. Robinson, M.D.; McCarthy, D.J.; Smyth, G.K. edgeR: A Bioconductor package for differential expression analysis of digital gene expression data. Bioinformatics 2010, 26, 139-140. [CrossRef] 